\title{
Distribution of mountain hawkweeds (Hieracium s. str.) in the Hrubý Jeseník Mountains
}

Jiří Kocián \& Jindřich Chrtek

\begin{abstract}
Distribution of mountain hawkweeds (Hieracium s. str.) in the Hrubý Jeseník Mountains. - Acta Mus. Siles. Sci. Natur., 66: 193-229, 2017.

Abstract: Field revision of current distribution of mountain hawkweeds (Hieracium s. str.) in the Hrubý Jeseník Mts was undertaken. Hieracium atratum, H. chlorocephalum, H. engleri, H. grabowskianum and $H$. plumbeum, whose last occurrence was documented many decades or even a century ago, were rediscovered. H. plumbeum was even found in new localities. The occurrence of $H$. alpinum, $H$. bifidum, $H$. chrysostyloides, $H$. inuloides, $H$. nigritum, $H$. prenanthoides, $H$. silesiacum, $H$. stygium and $H$. villosum was ascertained at many of their historical localities and a few new localities were found too. A neophyte species $H$. mixtum was discovered. Hieracium moravicum was not found. Accurate locality description and population size are provided for each finding. Herbarium revision and excerption of crucial literature were performed to provide historical distribution. Distributional changes as well as threatening and beneficial factors influencing Hieracium species in the Hrubý Jeseník Mts are discussed.
\end{abstract}

Key words: Hieracium, Hrubý Jeseník, distribution, field revision, rediscovery, mountain plants

\section{Introduction}

The Hrubý Jeseník Mountains (referred to below as "HJM", also as an adjective) are the second highest mountains range in the Czech Republic. Their botanical richness has been systematically studied for two centuries and current knowledge of the botanical richness of this area is at a high level (Bureš 2013). However, some plant groups, mainly the critical genera, cause persisting blank spaces in this knowledge. Although the distribution of the critical genus Hieracium s. str. (hawkweed) in these mountains was previously studied in detail by many authors in the past (e.g. Fiek 1881, Oborny 1906, Skřivánek 1956), contemporary knowledge of the species' distribution and population condition is very limited.

\section{Diversity of hawkweeds in the HJM}

Twenty species of hawkweeds occur in the HJM according to Chrtek (2004). Two ecological groups can be distinguished: hawkweeds that are fixed exclusively to the mountain environment (Hieracium villosum, H. grabowskianum, H. alpinum, H. chrysostyloides, H. atratum, $H$. prenanthoides, $H$. moravicum, $H$. engleri, $H$. nigritum, $H$. chlorocephalum, $H$. stygium, $H$. inuloides and $H$. silesiacum) and hawkweeds growing generally in lower altitudes reaching their altitudinal maxima in the HJM $(H$. diaphanoides, $H$. murorum, $H$. lachenalii and $H$. laevigatum). Between these groups, there is a transitional group of hawkweeds growing both in lowlands and in mountains (H. caesium, H. vulgatum, H. bifidum). This list of HJM hawkweeds is extended by two species recently discovered by J. Kocián in the HJM: H. mixtum Froel. (Kocián \& Chrtek 2011) and H. umbellatum (Novotná et al. 2013). Thus, twenty two hawkweed species are contemporarily known to occur in the HJM. This number, however, is not accurate due to taxonomical inconsistencies. Meanwhile taxons such as $H$. chrysostyloides, $H$. stygium or H. silesiacum are microspecies (more or less equal to subspecies according to Zahn 19221938), other taxons such as H. prenanthoides or H. inuloides are aggregate species comprising 
several yet taxonomically unresolved microspecies. Thus, the number of HJM species (on a microspecies level) is higher, but the exact number of them can only be known when all the local species have been taxonomically resolved. Since taxonomical research is not the aim of this article, we keep to the species classification and nomenclature given by Chrtek (2004) with one exception - we consider $H$. plumbeum a discrete species, not a subspecies of $H$. caesium.

In this article we focus on the species of the "mountain" group plus $H$. bifidum and H. plumbeum.

\section{History of hieraciology in the HJM}

The history of HJM hawkweed research from the beginning of the 19th century until the end of the first half of the 20th century is provided by Skřivánek (1956). To briefly summarize, HJM hawkweeds were systematically treated for the first time by Wimmer \& Grabowski (1829) and later by Grabowski (1843). The first monograph of the genus, including HJM species based on Wimmer's findings, was worked out by Fries (1862). Two crucial works comprehensively treating HJM hawkweeds followed: Uechtritz's treatement of the genus in Fiek's flora (Fiek 1881) and Oborny's monograph of Moravian hawkweeds (Oborny 1906). After that, Hruby (1914) specifies a large number of localities of many hawkweed species. The known data about HJM hawkweeds are summarized in Zahn's Hieracium monographs (Zahn 1921-1923 and even more comprehensive treatement Zahn 1922-1938) which are to date the most complex works on the whole genus. Skřivánek (1956) carried out field research on the south part of the HJM and its foothills and provided the findings of 16 Hieracium s. str. species. Since that time, no one has been systematically engaged in studying and monitoring HJM hawkweeds and only partial notes have been made about their distribution.

Jeník et al. (1983a, b) undertook detailed research of the flora and vegetation of Velká kotlina in the 1970s. They noticed six hawkweed species in the locality. Chrtek (1995) did a research on the Hieracium alpinum agg. and the Hieracium nigrescens agg. in the Eastern Sudeten Mts, treating HJM Hieracium alpinum and Hieracium chrysostyloides in detail. He also worked out the whole genus in Květena České republiky (Chrtek 2004). Štencl (2009) carried out a detailed revision of Hieracium villosum distribution in the HJM. Further data regarding recent findings of HJM hawkweeds are given in the flora inventories of HJM small scale protected areas (e.g. Kočí 2005, Albín 2005), however, some of the findings are dubious. Bureš (2013) worked out the flora of endangered HJM plants including all hawkweeds except the common ones. The treatment contains our preliminary field research results and in it many HJM hawkweeds are captured and published in colour photographs for the first time.

HJM hawkweeds were plentifully collected for herbarium purposes. However, herbarium specimens of only few species and only in selected, chiefly main herbaria were worked out: Hieracium alpinum and H. chrysostyloides by Chrtek (1995), H. villosum by Severa (2001), H. silesiacum by Szeląg (2004), H. bifidum by Zavadil (2007) and H. prenanthoides by Kocián (2012). A comprehensive treatment of HJM hawkweed herbarium collections is missing; for selected species it was worked out just recently (Kaplan et al. 2016).

The aims of this study are to (1) revise current distribution and population condition of the species in the field, (2) summarize historical distribution of HJM mountain hawkweeds based on herbarium revision and literature excerption, and (3) compare the current distribution with the historical one, discussing the distributional changes.

\section{Materials and methods}

The results are given to particular species in a standardized structure: introductory text, historical distribution in the HJM and current distribution in the HJM. The introductory text gives brief information about general species' distribution, distribution in the Czech Republic and in certain cases other specific or important notes. The historical 
distribution data is based on two sources: the herbarium specimens and literature. Herbarium specimens were studied in BRNM, BRNU, MP, OLM, OP, OVMB, PR, PRC, SUM and WRSL (acronyms according to Thiers 2017). Herbarium records are given in a standard format "collector, year of collection, herbarium acronym, (ID of herbarium specimen)" and are arranged by localities from the oldest records to the newest ones. The localities are arranged from north to south, general or unclear localities are put at the end. The literature locality data from the crucial HJM hieraciological works (Fiek 1881, Oborny 1885, Oborny 1906 and Skřivánek 1956) is presented in its original version. A text summarizing historical distribution follows, eventually mentioning additional important literature sources. Current distribution is based on the first author's extensive field research of the montane and subalpine zone of the whole main HJM ridge, i.e. from Šerák to Pec, which was undertaken between 2006 and 2016. The currently discovered/ascertained localities are given in the tables. Each finding comprises of: locality, GPS, altitude, date, count and herbarium evidence. Locality is described as accurately as possible with the information who noticed (not.) or collected (leg.) the specimens on the locality; GPS coordinates of WGS-84 are recorded by Garmin GPSmap 60CSx; altitude readings are measured from touristic map on www.mapy.cz; the date is the one when the species was first found in the locality during the field revision; the count is the number of flowering (fl.) or fruiting (fr.) stems, on occasions even sterile (st.) plants were counted (in cases when flowering or fruiting stems were not present) and the number given is either accurate in case of small populations or rounded up in the case of larger populations - then $\mathrm{T}=$ tens and $\mathrm{H}=$ hundreds, e.g. $8 \mathrm{~T} \mathrm{fl}$. $=$ ca 80 flowering stems; herbarium evidence gives information on whether a herbarium specimen was taken and if so, in which herbarium it is deposited, acronyms are according to Thiers 2017 (acronym KOC means the specimen was still in the first author's private herbarium at the time of the article publication). The tables are followed by a text describing the present species' occurrence in the HJM, a comparision of the historical distribution with the contemporary one, a discussion of population abundance trends and in some cases information about the observed morphological variability within/between populations in addition to other noteworthy observations.

\section{Results}

\section{Hieracium alpinum L.}

The range of Hieracium alpinum s. str. is not known, but it is presumably similar to the range of the whole Hieracium alpinum agg. (Chrtek 1995), which has a typical arcto-alpine range (cf. Bräutigam 1992). In the Czech Republic, Hieracium alpinum s. str. occurs in the Krkonoše Mts and the HJM (Chrtek 2004).

\section{Historical distribution in the HJM}

Herbarium specimens: Šerák: Spitzner 1892 BRNU (377361); Laus 1904 OLM (68662); Horák 1930 MP (59056); Horňanský 1947 BRNM (422230); Hynšt 1947 OLM (128612, 129756, 129757); Tomášek 1947 BRNM (422225); Jedlička 194? BRNU (s.n.); Skřrivánek 1956 BRNM (251999); Bureš 1986 OLM (118834); Keprník: Oborny 1879 BRNU (335710); Bubela 1883 BRNU (335713); Müller 1886 BRNM (68444); Spitzner 1892 BRNU (377362); Baenitz 1893 WRSL (s.n.); Frimmel 1912 BRNU (308798); Staněk 1919 BRNU (314503); Černohorský 1947 PR (250169); Hynšt, Weber 1947 OLM (128611); Müller 1947 (405172); Svrček 1947 PR (P4S417/5102); Hrabětová 1959 BRNU (373771); Hynšt 1953 OLM (128608); Magurová(?) 1955 PR (P4S417/7716); Šula 1966 OLM (115211); Pospíšil 1966 BRNM (42222?); Chrtek, Chrtková 1979 PR (P4S417/9992); Žalostná: Skřivánek 1956 BRNM (251998); Vozka: Černohorský 1947 PR (P4S417/7500); Vřesová studánka (Červená hora): Teuber 1897 BRNM (18810); Šourek, Kurka 1947 PR (269824); Malý Děd: Bubela 1883 BRNU (335?03); Tabulové skály: Müller 1886 BRNM (68443); Müller 1889 BRNM (68449); Šmarda 1920 PR (109200); Skřivánek 1955 BRNM (252001); Janáčková 1969 SUM (5172); Velký Děd: Skřivánek 1955 BRNM (252004); Praděd: Oborny 1867 BRNU (335707, 335711); Oborny 1879 BRNU (335705); Müller 1886 BRNM (68442); Schierl 1890 BRNM (46008); Callier, Hirte, Scholz 1893 WRSL (s.n.); Skřivánek 1909 BRNM (251996); Staněk 1919 BRNU (314506); Staněk 1920 BRNU (335693); Laus 1926 OVMB (B3891); Laus 1930 OLM (68661); Laus 1930 PRC (s.n.); Weber 1934 PR (P4S417/9150); Skřivánek 1946 BRNM (251989, 251990); Kvapilík 1947 OLM (92575); Deyl 1949 PR (P4S417/7410); Deyl 1965 OLM (153179); Mravenečník: Jedlička 1946 BRNU (335638); Petrovy kameny: Oborny 1877 BRNU (64292); Freyn 1883 BRNU (335712); Spitzner 1888 BRNU (377363); Spitzner 1889 BRNU (351943); Krajina 1946 PRC (s.n.); Skřivánek 1946 BRNU (360962); Deyl 1949 PR (P4S417/7414); Součková 1949 BRNM (46005); Janáčková 1971 SUM (6698); Janáčková 1978 SUM (13776); Teuber 1903 BRNM (18811); Skřivánek 1915 BRNM (251984); Skřivánek 1915 BRNM (251987); Laus 1928 OP (20334); Zavřel 1947 BRNM (251997); Skřivánek 1955 BRNM (252002); Burša 1969 OP (128370); Vysoká hole: Poleck 1841 WRSL (s.n.); Kern 1874 WRSL (s.n.); Freyn 1883 BRNU (335709); Rieger 1890 OLM (88907); Rieger 1890 OP (96766); Kunisch 1893 WRSL (s.n.); Laus 1904 BRNU (413101); Richter 1906 SUM 
(1000); Horák 1931 MP ( 59057); Thenius 1933 BRNU (332386); Kvapilík 1936 OLM (92548, 92550); Šmarda 1946 BRNM (18802, 18803); David 1953 MP (28922); Skřrivánek 1955 BRNM (252003); Deyl 1965 OLM (153173); Burešovi, Jeník 1975 OLM (109668); Burešovi, Jeník 1976 OLM (109647); Kolenati s.d. PR (P4S417/6889); Kamzičník: Skřivánek 1955 BRNM (252005); Burešovi, Jeník 1974 OLM (109675); Velká kotlina: Suza 1909 BRNM (06899/32.); Dvořák \& Suza 1911 BRNM (06898/32.); Thenius 1919 BRNU (332335); Pospíšil 1946 BRNM (78985); Burešovi, Jeník 1972 OLM (109674); Velký máj: Čouka 1905 BRNU (413139); Laus 1931 OP (97315); Kvapilík 1947 OLM (92574); Hrabětová 1959 BRNU (404144); Jelení hřbet: Gams 1907 BRNM (18806); in subalpinis mt. Šerák et Keprník: Deyl 1947 PR (P4S417/7393); Schäferei[?]: Skřivánek 1909 BRNM (251086); Wege vom Jagdhaus zu den Drei Brunnen: Lukas 1923 SUM (9889); Skály na Pradědu, Praděd, Petrovy kameny, Vysoká hole: Júlek 1948 BRNM (422229); Vysoká hole-Jelení hřbet: Čouka 1905 BRNU (413003); Hrubý Jeseník: Schierl 1887 BRNM (18805); Frimmel s.d. BRNU (308804).

Literature data: Fiek 1881: Im Gesenke [no specific localities given] Oborny 1885: Grasreiche und steinige Abhänge und Kuppen des Sudetenzuges über der Holzregion, seltener in das Waldgebiet hineinragend, stellenweise oft massenhaft. (ut H. alpinum L. $\alpha$ ) genuinum:) Seltener und zerstreut, am häufigsten noch auf dem Köpernik. (ut H. alpinum L. $\beta$ ) holosericeum:) Petersteine, Hohe-Heide, Altvater, Ameisenhügel, Schieferheide, Hirschbrunnen etc. (ut H. foliosum Wimm.:) im Gesenke. Oborny 1906: (ut H. alpinum L. ssp. alpinum Tsch.:) Die typische Form auf den Kämmen des Gesenkes [...], am Köpernik, Hochschar, Fuhrmannstein; $\beta$ verbreiteret, an obigen Standorten und vom Köpernik längs des Kammes bis zur Schieferheide, so auf der Brünnelheide, auf dem Hausberge, Altvater, Peterstein hohe Heide, Heiligenhübel, Ameisenhügel, Hirschbrunnen, stellenweise sehr häufig; $\gamma$ Köpernik bei Goldenstein. (ut H. alpinum L. ssp. melanocephalum Tsch.:) Die Normalform auf der Hochschar, dem Köpernik, Peterstein; $\beta$ auf dem Altvater und sonst zerstreut. Skřivánek 1956: (ut H. holosericeum Backh.:) Nápadný jestřábník, charakteristický pro hřebeny, temena hor a vrcholové skály. Často pospolitě a v menších koloniích společně s $H$. nigritum Uechtr. a $H$. stygium Uechtr., ve společenství s Festuca supina, Deschampsia flexuosa, Vaccinium myrtillus, Calluna vulgaris, Mutellina purpurea, Solidago alpestris, Achyrophorus uniflorus. Výskytem omezen na horské hole v pásmu 1350-1490 m. Břidličná 5. 8. 1946, Máj, Svatá, Vysoká hole, Petrova skála 6. 8. 1955, Praděd, Tabulové kameny, Velký Děd, Jelení hřbet 7. 8. 1955.

Many localities of Hieracium alpinum are known from the whole HJM ridge from Šerák to Břidličná hora. Chrtek (1995) gives a detailed list of historical and at that time recently confirmed localities (though some of them are dubious - Vřesová studánka and Malá kotlina, or highly probably wrong - Volárna). He also analyses a complicated taxonomical treatment of Hieracium alpinum agg. in the HJM. Recently, Kočí (2005) states that there are relatively abundant populations on Tabulové skály, nearby Petrovy kameny and on the slopes of Vysoká hole to Petrovy kameny and that the species is rare elsewhere in the Praděd National Nature Reserve. Albín (2005) reports the distribution of the species from the summit areas of Šerák and Keprník in the Šerák-Keprník National Nature Reserve.

\section{Current distribution in the HJM}

Table 1: Current localities of Hieracium alpinum in the HJM

\begin{tabular}{|l|l|l|l|l|l|}
\hline Locality & GPS & Alt. & Date & Count & Herb. \\
\hline $\begin{array}{l}\text { Šrák, alpine grassland along the tourist path between } \\
\text { chairlift upper exit and Jiŕího chalet, leg. J. Kocián }\end{array}$ & $\begin{array}{l}50^{\circ} 11^{\prime} 13.4^{\prime \prime N} \\
17^{\circ} 06^{\prime} 21.5^{\prime \prime}\end{array}$ & 1340 & 15.7 .2008 & $1 \mathrm{H}$ fl. & NJM \\
\hline $\begin{array}{l}\text { Šrák, scree partially covered by soil } 20 \text { m under } \\
\text { the belfry, 100 m SSE of Jiř́ho chalet, not. R. Štencl }\end{array}$ & $\begin{array}{l}50^{\circ} 11^{\prime} 11.2^{\prime \prime} \mathrm{N} \\
17^{\circ} 06^{\prime} 33.6^{\prime \prime} \mathrm{E}\end{array}$ & 1315 & 7.5 .2014 & $\begin{array}{l}15 \mathrm{fl} . \\
(2015)\end{array}$ & - \\
\hline $\begin{array}{l}\text { Keprník, rocks } 130 \mathrm{~m} \text { NW of the summit, } \\
\text { not. J. Kocián }\end{array}$ & $\begin{array}{l}50^{\circ} 10^{\prime} 18.5^{\prime \prime N} \\
17^{\circ} 06^{\prime} 56.8^{\prime \prime} \mathrm{E}\end{array}$ & 1410 & 11.9 .2012 & $\begin{array}{l}5 \mathrm{~T} \text { fl. } \\
(2014)\end{array}$ & - \\
\hline $\begin{array}{l}\text { Keprník, alpine grassland around the summit rock, } \\
\text { leg. J. Kocián }\end{array}$ & $\begin{array}{l}50^{\circ} 10^{\prime} 15.7^{\prime \prime N} \\
17^{\circ} 06^{\prime} 59.0^{\prime \prime} \mathrm{E}\end{array}$ & 1422 & 15.7 .2008 & $5 \mathrm{~T}$ fl. & NJM \\
\hline $\begin{array}{l}\text { Žalostná, alpine grassland and small bushes on } \\
\text { the rocks, not. J. Kocián }\end{array}$ & $\begin{array}{l}50^{\circ} 10^{\prime} 18.6^{\prime \prime N} \\
17^{\circ} 07^{\prime} 38.3^{\prime \prime} \mathrm{E}\end{array}$ & 1350 & 11.9 .2012 & $2 \mathrm{~T}$ fr. & - \\
\hline $\begin{array}{l}\text { Sokol, Sokolí skála, summit area of the main rock, } \\
\text { not. J. Kocián }\end{array}$ & $\begin{array}{l}50^{\circ} 05^{\prime} 40.5^{\prime \prime N} \\
17^{\circ} 15^{\prime} 00.9^{\prime \prime} \mathrm{E}\end{array}$ & 1155 & 16.9 .2012 & $\begin{array}{l}1 \mathrm{H} \text { fl. } \\
(2015)\end{array}$ & - \\
\hline
\end{tabular}




\begin{tabular}{|c|c|c|c|c|c|}
\hline Locality & GPS & Alt. & Date & Count & Herb. \\
\hline $\begin{array}{l}\text { Tabulové skály, alpine grassland on the rocks, rocks } \\
\text { themselves and around the path leading to them from } \\
\text { Praděd, not. J. Kocián }\end{array}$ & $\begin{array}{l}50^{\circ} 05^{\prime} 11.3^{\prime \prime} \mathrm{N} \\
17^{\circ} 13^{\prime} 50.8^{\prime \prime} \mathrm{E}\end{array}$ & 1450 & 1. 8. 2012 & $\begin{array}{l}\text { 4H fl. } \\
(2016)\end{array}$ & - \\
\hline $\begin{array}{l}\text { Praděd, alpine grassland } 210 \mathrm{~m} \mathrm{~N} \text { of the summit, } \\
\text { around the border stone and in surroundings, leg. } \\
\text { J. Kocián }\end{array}$ & $\begin{array}{l}50^{\circ} 05^{\prime} 05.4^{\prime \prime} \mathrm{N} \\
17^{\circ} 13^{\prime} 54.6^{\prime \prime} \mathrm{E}\end{array}$ & 1480 & 9.7 .2006 & $3 \mathrm{~T} \mathrm{fl}$. & NJM \\
\hline $\begin{array}{l}\text { Praděd, alpine grassland, } 100 \mathrm{~m} \mathrm{~N} \text { of the summit, } \\
\text { not. J. Kocián }\end{array}$ & $\begin{array}{l}50^{\circ} 05^{\prime} 02.3^{\prime \prime} \mathrm{N} \\
17^{\circ} 13^{\prime} 51.9^{\prime \prime} \mathrm{E}\end{array}$ & 1485 & 12. 7. 2015 & $5 \mathrm{~T} \mathrm{fl.}$ & - \\
\hline $\begin{array}{l}\text { Praděd, alpine grassland surrounding an unused path } \\
\text { on SW slope of the mountain, scattered in a larger } \\
\text { area spreading from the coordinates up towards the } \\
\text { summit, not. J. Kocián }\end{array}$ & $\begin{array}{l}50^{\circ} 04^{\prime} 56.1^{\prime \prime N} \\
17^{\circ} 13^{\prime} 41.6^{\prime \prime} \mathrm{E}\end{array}$ & 1475 & 12.7 .2015 & $4 \mathrm{H} \mathrm{fl}$. & - \\
\hline $\begin{array}{l}\text { Praděd, S slope, stony ruin of a former chalet, } 350 \\
\text { m SSE of altitudinal point } 1356 \text { and } 900 \mathrm{~m} \\
\text { E of Barborka chalet, not. J. Kocián }\end{array}$ & $\begin{array}{l}50^{\circ} 04^{\prime} 42.1^{\prime \prime} \mathrm{N} \\
17^{\circ} 14^{\prime} 38.5^{\prime \prime} \mathrm{E}\end{array}$ & 1280 & 19.8. 2013 & $4 \mathrm{~T}$ st. & - \\
\hline $\begin{array}{l}\text { Petrovy kameny, alpine grassland around the rock, } \\
\text { not. J. Kocián }\end{array}$ & $\begin{array}{l}50^{\circ} 04^{\prime} 07.2^{\prime \prime} \mathrm{N} \\
17^{\circ} 14^{\prime} 01.4^{\prime \prime} \mathrm{E} \\
\end{array}$ & 1435 & 20.7 .2013 & $5 \mathrm{~T} \mathrm{fl.}$ & - \\
\hline $\begin{array}{l}\text { Petrovy kameny, alpine grassland on the edge of } \\
\text { a path between the rock and the red tourist path, leg. } \\
\text { J. Kocián }\end{array}$ & $\begin{array}{l}50^{\circ} 04^{\prime} 02.9^{\prime \prime} \mathrm{N} \\
17^{\circ} 14^{\prime} 05.1^{\prime \prime} \mathrm{E}\end{array}$ & 1430 & 16. 7. 2008 & several & NJM \\
\hline $\begin{array}{l}\text { Vysoká hole, alpine grassland, near the red tourist } \\
\text { path, leg. J. Kocián }\end{array}$ & $\begin{array}{l}50^{\circ} 03^{\prime} 53.3^{\prime \prime} \mathrm{N} \\
17^{\circ} 14^{\prime} 05.0^{\prime \prime} \mathrm{E} \\
\end{array}$ & 1460 & 16. 7. 2008 & $3 \mathrm{~T} \mathrm{fl}$. & NJM \\
\hline $\begin{array}{l}\text { Vysoká hole, alpine grassland, } 120 \mathrm{~m} \mathrm{SE} \text { of the field } \\
\text { station, not. J. Kocián }\end{array}$ & $\begin{array}{l}50^{\circ} 03^{\prime} 31.9^{\prime \prime} \mathrm{N} \\
17^{\circ} 13^{\prime} 56.8^{\prime \prime} \mathrm{E}\end{array}$ & 1460 & 29.8 .2015 & $1 \mathrm{~T}$ st. & - \\
\hline $\begin{array}{l}\text { Kamzičník, alpine grassland, by the red tourist path, } \\
\text { leg. J. Kocián }\end{array}$ & $\begin{array}{l}50^{\circ} 03^{\prime} 10.5^{\prime \prime} \mathrm{N} \\
17^{\circ} 13^{\prime} 36.1^{\prime \prime} \mathrm{E} \\
\end{array}$ & 1420 & 16. 7. 2008 & $1 \mathrm{~T} \mathrm{fl}$. & NJM \\
\hline $\begin{array}{l}\text { Břidličná, wind-swept vegetation with dwarf shrubs, } \\
140 \text { m SWW of the summit, not. J. Kocián }\end{array}$ & $\begin{array}{l}50^{\circ} 01^{\prime} 58.4^{\prime \prime N} \\
17^{\circ} 11^{\prime} 06.7^{\prime \prime} \mathrm{E}\end{array}$ & 1345 & 12.7 .2015 & $5 \mathrm{fl}$. & - \\
\hline
\end{tabular}

We confirmed the occurrence of Hieracium alpinum on most historical localities. The majority of them lie in the topmost areas of the main HJM ridge with two populations (Sokol and Praděd - ruin of a former chalet) surprisingly descending to lower altitudes. It is characteristic that the populations consist either of sterile plants or that the number of sterile plants far exceeds the number of the flowering ones.

We were not successful in confirming the species' occurrence on Vozka, Červená hora, Velká kotlina, Velký máj, Jelení hřbet and Sut'. Although some of these historical localities are dubious, a decrease in population abundance, reduced vitality and even presumed extinction of some populations of Hieracium alpinum in the HJM had been noted by Chrtek (1995). Hieracium alpinum is also heavily grazed by herbivore mammals - at many localities only a fraction of plants, if any at all, successfully fructify.

\section{Hieracium atratum agg.}

The range of this aggregate species comprises Greenland, Northern Europe from Iceland to the Ural Mts and also the higher mountains of Central Europe (Zahn 1922-1938). In the Czech Republic it is abundant in the Krkonoše Mts and rare on Mt. Králický Sněžník and in the HJM (Zahn 1.c.). 


\section{Historical distribution in the HJM}

Herbarium specimens: Keprník: Bubela 1883 BRNM (46072); Bubela 1884 PR (s.n.); Bubela 1884 PRC (s.n.); Baenitz 1893 PRC (s.n.); Oborny 1895 PRC (s.n.); Oborny 1899 BRNM (46073, 46074, 46075, 46076); Oborny 1899 PRC (s.n.); Oborny 1900 BRNM (46071); Dostál 1947 PRC (s.n.).

Literature data: Fiek 1881: Für das Gesenke zweifelhaft. Oborny 1885: Als Seltenheit auf dem Köpernik (Bl. 1883). Oborny 1906: Auf dem Gipfel oberhalb der Köperniksteine auf dem Köpernik, hier truppweise. Skřrivánek 1956: [not mentioned].

According to herbarium data only a few botanists have documented the occurrence of Hieracium atratum agg. in the HJM and all of them from only the single locality of Keprník. Apart from this locality, Praděd and Šerák are mentioned by Zahn (1922-1938). Hieracium atratum agg. was last documented in the end of the first half of the 20th century. Since that time it has been neither collected nor reliably reported on from the HJM.

\section{Current distribution in the HJM}

Table 2: Current localities of Hieracium atratum agg. in the HJM

\begin{tabular}{|l|l|l|l|l|l|}
\hline Locality & GPS & Alt. & Date & Count & Herb. \\
\hline $\begin{array}{l}\text { Keprník, summit area, thufur covered mainly by } \\
\text { grasses } 15 \text { m N of the summit, not. J. Kocián }\end{array}$ & $\begin{array}{l}50^{\circ} 10^{\prime} 15.9^{\prime \prime} \mathrm{N} \\
17^{\circ} 06^{\prime} 59.3^{\prime \prime}\end{array}$ & 1423 & 4.7 .2016 & $1 \mathrm{fl}$. & - \\
\hline $\begin{array}{l}\text { Keprník, crevices on E base of the summit rock and } \\
\text { alpine grassland nearby, leg. J. Kocián }\end{array}$ & $\begin{array}{l}50^{\circ} 10^{\prime} 15.4^{\prime \prime} \mathrm{N} \\
17^{\circ} 06^{\prime} 59.5^{\prime \prime} \mathrm{E}\end{array}$ & 1422 & 8.7 .2015 & $8 \mathrm{fl}$. & BRNM \\
\hline $\begin{array}{l}\text { Keprník, summit area, thufur covered mainly by } \\
\text { dwarf-shrub vegetation 18 m SW of the summit, not. } \\
\text { J. Kocián }\end{array}$ & $\begin{array}{l}50^{\circ} 10^{\prime} 15.0^{\prime \prime} \mathrm{N} \\
17^{\circ} 06^{\prime} 58.5^{\prime \prime} \mathrm{E}\end{array}$ & 1423 & 4.7 .2016 & $1 \mathrm{fl.}$ & - \\
\hline $\begin{array}{l}\text { Keprník, summit area, dwarf-shrub vegetation } 19 \mathrm{~m} \\
\text { S of the summit, not. J. Kocián }\end{array}$ & $\begin{array}{l}50^{\circ} 10^{\prime} 14.8^{\prime \prime} \mathrm{N} \\
17^{\circ} 06^{\prime} 59.1^{\prime \prime} \mathrm{E}\end{array}$ & 1422 & 4.7 .2016 & $1 \mathrm{fl.}$ & - \\
\hline
\end{tabular}

We rediscovered Hieracium atratum agg. at its traditional locality of Keprník. The occurrence is confined to the summit area of Keprník and the population is very small.

\section{Hieracium bifidum agg.}

The range of this aggregate species comprises Northern Europe from Iceland to Finland and the higher mountains of Central and Southern Europe; it grows only insularly elsewhere in Central Europe, especially in the areas with limestone outcrops; isolated populations also exist in Russia in the Ural Mts and the Valdai Hills (Zahn 1922-1938). In the Czech Republic it has a disjunct distribution - it grows predominantly in floristically rich areas with basic bedrock (cf. Zavadil 2007).

\section{Historical distribution in the HJM}

Herbarium specimens: Velká kotlina: Podpěra 1912 BRNU (4456?); Danihelka 1996 BRNU (626065)

Note: Zavadil (2007) presents another herbarium specimen of Hieracium bifidum [Skřivánek BRNM 1956 (n.?)] from Velká kotlina. We were not able to find this specimen in the herbarium.

Literature data: Fiek 1881: Gesenke: Falkenfelsen bei Gabel (Oborny). Oborny 1885: Falkensteine am Abhange des Altvaters gegen Gabel, 1876 entdeckt. Oborny 1906: Kesselsteine im grossen Kessel und auf den Falkensteinen bei Gabel, nach Formanek auch auf der Donnerlahn und auf dem Schafberge bei Karlsbrunn. Skřivánek 1956: [not mentioned].

Only two localities of Hieracium bifidum agg. are historically known from the HJM Sokolí skála which we did not find documented by any herbarium specimen, and Velká kotlina. 
Formánek's localities Donnerlahn and Schafberg mentioned by Oborny (1906) were refuted by Formánek (1886) himself.

\section{Current distribution in the HJM}

Table 3: Current localities of Hieracium bifidum agg. in the HJM

\begin{tabular}{|c|c|c|c|c|c|}
\hline Locality & GPS & Alt. & Date & Count & Herb. \\
\hline Plošina, rocks on a N slope, not. R. Štencl & $\begin{array}{l}50^{\circ} 07^{\prime} 14.7^{\prime \prime} \mathrm{N} \\
17^{\circ} 19^{\prime} 15.6^{\prime \prime} \mathrm{E}\end{array}$ & 930 & 29.8 .2013 & $>1 \mathrm{~T} \mathrm{fl}$ & - \\
\hline $\begin{array}{l}\text { Plošina, N slope, rocky ridge of up to } 10 \mathrm{~m} \text { high } \\
\text { sunny rocks, not. R. Stencl }\end{array}$ & $\begin{array}{l}50^{\circ} 07^{\prime} 10.7^{\prime \prime} \mathrm{N} \\
17^{\circ} 19^{\prime} 17.7^{\prime \prime} \mathrm{E}\end{array}$ & 960 & 29.8 .2013 & $1 \mathrm{~T} \mathrm{fl.}$ & - \\
\hline $\begin{array}{l}\text { Sokol, Sokolí skála and the rock } 45 \mathrm{~m} \mathrm{~W} \text { of it, } \\
\text { uppermost grassy parts of the rocks, crevices on } \\
\text { the rock walls, screes and grasslands in the vicinity } \\
\text { of the rocks, leg. J. Kocián }\end{array}$ & $\begin{array}{l}\text { many } \\
\text { microlocalities }\end{array}$ & $\begin{array}{l}1135 \\
- \\
1170\end{array}$ & 10.7 .2007 & $\begin{array}{l}>8 \mathrm{~T} \mathrm{fl} . \\
(2016)\end{array}$ & $\begin{array}{l}\text { NJM, } \\
\text { BRNU }\end{array}$ \\
\hline $\begin{array}{l}\text { Divoký důl, rocks in a mountain mixed forest, } \\
\text { scattered individual plants on more places, not. } \\
\text { R. Štencl }\end{array}$ & $\begin{array}{l}\text { around } \\
50^{\circ} 04^{\prime} 44.5^{\prime \prime} \mathrm{N} \\
17^{\circ} 12^{\prime} 02.3^{\prime \prime} \mathrm{E}\end{array}$ & 1020 & 4. 8.2014 & $1 \mathrm{~T} \mathrm{fl.}$ & - \\
\hline $\begin{array}{l}\text { Jelení hřbet, rocks in a mountain mixed forest on a } \\
\text { steep N slope ca } 780 \mathrm{~m} \mathrm{NW} \text { of the summit, not. } \\
\text { J. Kocián }\end{array}$ & $\begin{array}{l}50^{\circ} 02^{\prime} 44.7^{\prime \prime} \mathrm{N} \\
17^{\circ} 11^{\prime} 41.9^{\prime \prime} \mathrm{E}\end{array}$ & 1125 & 10.7 .2016 & $1 \mathrm{fl}$. & - \\
\hline $\begin{array}{l}\text { Jelení hřbet, rocks in a mountain mixed forest on a } \\
\text { steep N slope ca } 780 \mathrm{~m} \mathrm{NW} \text { of the summit, not. } \\
\text { J. Kocián }\end{array}$ & $\begin{array}{l}50^{\circ} 02^{\prime} 45.9^{\prime \prime} \mathrm{N} \\
17^{\circ} 11^{\prime} 41.4^{\prime \prime} \mathrm{E}\end{array}$ & 1105 & 10.7 .2016 & $3 \mathrm{fl}$. & - \\
\hline $\begin{array}{l}\text { Jelení hřbet, rocks in a mountain mixed forest on a } \\
\text { steep N slope ca } 780 \mathrm{~m} \mathrm{NW} \text { of the summit, not. } \\
\text { J. Kocián }\end{array}$ & $\begin{array}{l}50^{\circ} 02^{\prime} 44.4^{\prime \prime} \mathrm{N} \\
17^{\circ} 11^{\prime} 45.1^{\prime \prime} \mathrm{E}\end{array}$ & 1115 & 10.7 .2016 & $2 \mathrm{fl}$. & - \\
\hline $\begin{array}{l}\text { Břidličná, Čertova stěna, rocks in a mountain mixed } \\
\text { forest } 190 \text { m SE of Čertova stěna (altitudinal point } \\
\text { 1075), not. R. Štencl }\end{array}$ & $\begin{array}{l}50^{\circ} 02^{\prime} 23.1^{\prime \prime} \mathrm{N} \\
17^{\circ} 11^{\prime} 15.9^{\prime \prime} \mathrm{E}\end{array}$ & 1020 & 26. 8. 2014 & $1 \mathrm{~T} \mathrm{fl}$. & - \\
\hline
\end{tabular}

We confirmed the occurrence of Hieracium bifidum agg. on the oldest known locality of Sokolí skály where it has relatively rich population. R. Štencl revised Hieracium bifidum agg. on the northern slope of Jelení hřbet (locality noted by Albín 2006 and Kočí 2009) and on the northern slope of Břidličná on Čertova stěna (locality noted by Kočí 2009) in 2013. He also newly found the species on Plošina and Divoký důl. We visited the locality Jelení hřbet and found three micropopulations (there are possibly more - we did not explore the wider area). These four newly discovered localities suggest that Hieracium bifidum agg. may occur on more localities in the HJM on botanically poorly explored remoted rocks.

We did not find the species in Velká kotlina but its persisting occurrence is likely.

\section{Hieracium chlorocephalum R. Uechtr.}

Hieracium chlorocephalum is known from the Krkonoše Mts and the HJM (Zahn 19221938) and it is most probably endemic to these mountain ranges (Chrtek 2004).

\section{Historical distribution in the HJM}

Herbarium specimens: Vysoká hole: Laus 1908 BRNU (28469); Velká kotlina: Freyn 1878 BRNM (s.n.); Freyn 1878 BRNM (s.n.); Freyn 1878 BRNM (s.n.); Freyn 1878 PR (P4S417/549); Oborny 1879 BRNM (s.n.); Oborny 1879 BRNM (s.n.); Oborny 1879 PRC (s.n.); Winkler 1879 WRSL (s.n.); Fiek 1880 WRSL (s.n.); Oborny 1882 PRC (s.n.); Ficinus 1883 WRSL (s.n.); Freyn 1883 BRNM (s.n.); Freyn 1883 BRNM (s.n.); Freyn 1883 PRC 
(s.n.); Bubela 1884 PRC (s.n.); Oborny 1886 BRNM (s.n.); Oborny 1886 BRNU (377367); Fiek 1895 WRSL (s.n.); Oborny 1903 BRNU (64253); Oborny 1903 PR (P4S417/550); Oborny 1903 BRNM (s.n.); Oborny 1903 PRC (s.n.); Teuber 1903 BRNM (252323); Laus 1908 BRNM (s.n.); Laus 1908 BRNU (27741); Otruba 1930 OLM (68880); Otruba 1931 PR (P4S417/9383); Skřivánek 1946 BRNM (252322); Deyl 1949 PR (P4S417/7416, P4S417/7417, P4S417/7418); Skřivánek 1953 BRNM (252355); Deyl 1966 PR (P4S417/8095); Grabowski s.d. WRSL (s.n.); Zlatník s.d. PR (P4S417/10518); Grützenberg: Krause s.d. WRSL (s.n.).

Literature data: Fiek 1881: im Gesenke nur im gr. Kessel! (U., Bchm.). Oborny 1885: Grasige und steinige Abhänge, im Hochgesenke, selten. Im grossen Kessel (Ue) und zwar am oberen Rande, den Standort mit H. Engleri theilend, überdies noch unter den Fuhrmannsteinen, hier sehr selten (August 1879). Oborny 1906: Grasige und steinige Abhänge, Felshänge, zerstreut im Gesenke und selten. Grosser Kessel u. z. am mittleren und unteren Rande desselben, Abhänge der hohen Heide, am Klein-Mohrauer Gebirgswege, ziemlich nahe an der hohen Heide, am rothen Berge (Bänitz) und in schwächlicheren Exemplaren um die Fuhrmannsteine. Skřivánek 1956: horské stráně a skály ve Velkém Kotli, nehojně, 28. 6. 1946 a 4. 8. 1953.

The principal locality of Hieracium chlorocephalum in the HJM is Velká kotlina. Sole herbarium specimens are located from Vysoká hole and Grützenberg. A few other localites are mentioned in the literature. Similarly to Hieracium atratum agg., Hieracium chlorocephalum was last documented in the end of the first half of the 20th century. Since that time it has been neither collected nor reliably reported from the HJM.

\section{Current distribution in the HJM}

Table 4: Current localities of Hieracium chlorocephalum in the HJM

\begin{tabular}{|l|l|l|l|l|l|}
\hline Locality & GPS & Alt. & Date & Count & Herb. \\
\hline $\begin{array}{l}\text { Velká kotlina, upper part of Vitáskova rokle, edge } \\
\text { and rocky slope under the path crossing the ravine, } \\
\text { leg. J. Kocián }\end{array}$ & $\begin{array}{l}50^{\circ} 03^{\prime} 22.6^{\prime \prime} \mathrm{N} \\
17^{\circ} 14^{\prime} 08.5^{\prime \prime} \mathrm{E}\end{array}$ & 1320 & 23.7 .2016 & $2 \mathrm{~T}$ fl. & BRNU \\
\hline
\end{tabular}

We rediscovered Hieracium chlorocephalum in a single locality in Velká kotlina in one of the local floristical hotspots - the upper part of Vitáskova rokle. Population is small but seems to be stable. Even so Hieracium chlorocephalum is one of the rarest HJM hawkweeds.

We were not successful in confirming the species on Vozka, Červená hora and Vysoká hole.

\section{Hieracium chrysostyloides (Zahn) Chrtek fil.}

Hieracium chrysostyloides is one of the most remarkable hawkweed species in the HJM. It is endemic of the highest Eastern Sudeten mountain ranges - Mt. Králický Sněžník and the HJM (Chrtek 1995). The species is very interesting cytogenetically: it is a pentaploid (Chrtek 1996, Kocián 2013); there are only five pentaploid Hieracium species known worldwide currently (Stace et al. 1995, Pulkina \& Tupitsyna 2000, Tyler \& Jönsson 2009).

\section{Historical distribution in the HJM}

Herbarium specimens: Šerák: s. coll. 1896 PRC (s.n.); Oborny 1902 PRC (s.n.); Laus 1904 OLM (69254); Kruber 1924 WRSL (s.n.); Keprník: Oborny 1873 PRC (s.n.); Skřivánek 1956 BRNM (252015); Vřesová studánka (Červená hora): Bubela 1884 PRC (s.n., s.n.); Oborny 1886 BRNM (s.n., s.n.); Oborny 1886 PRC (s.n.); Oborny 1893 PRC (s.n.); Teuber 1897 BRNM (18810); Horák 1931 MP (59144); Horák 1947 MP (59127); Šourek, Kurka 1947 PR (269501); Hynšt 1953 OLM (128609); Novotný 1956 BRNM (422228); Skřivánek 1956 BRNM (252036, 252019); Deyl 1960 OLM (153176); Tabulové skály: Oborny 1879 PRC (s.n.); Laus 1930 OP (20387); Skřivánek 1955 BRNM (252009); Praděd: Oborny 1867 BRNU (61745); Freyn 1883 BRNM (s.n.); Müller 1886 BRNM (68440); Oborny 1887 BRNU (377365); Spitzner 1888 BRNU (135398, 195353); Müller 1889 BRNM (252024); Callier, Hirte, Scholz 1893 PRC (s.n.); Freyn 1893 PRC (s.n.); Teuber 1897 BRNM (18807); Laus 1909 BRNM (s.n.); Kruber 1931 WRSL (s.n.); Kvapilík 1947 OLM (92570); Deyl 1949 PR (P4S417/7403, P4S417/7411, P4S417/7404); Novotný 1956 BRNM (422227); Skřivánek 1946 BRNM (251990); Hochstetter s.d. BRNM (s.n.); s.coll. s.d. PRC (s.n.); Petrovy kameny: Freyn 1883 BRNM (s.n., s.n.); Oborny 1886 PRC (s.n., s.n.); Teuber 
1902 BRNM (18809); Laus 1907 BRNU (27672); Laus 1907 BRNM (s.n.); Laus 1908 BRNM (252029); Laus 1908 BRNU (159152, 28364); Sedláček 1909 BRNU (09381); Laus 1911 BRNU (28363); Skřivánek 1915 BRNM (251995); Laus 1921 OVMB (B3819); Kruber 1924 WRSL (s.n.); Laus 1930 PRC (s.n.); Thenius 1933 BRNU (332383); Krajina 1946 PRC (s.n.); Skřivánek 1946 BRNU (360962); Horák 1947 MP (59124, 59131); Součková 1949 BRNM (46606); Skřivánek 1955 BRNM (252034); Kleine Heide: Freyn 1878 BRNM (s.n.); Vysoká hole: Freyn 1883 BRNM (s.n.); Formánek 1886 BRNM (s.n.); Oborny 1886 OLM (69252, 69253); Oborny 1886 PRC (s.n.); Spitzner 1888 BRNU (195352, 195400, 377364); Hora 1889 PRC (s.n.); Rieger 1890 OP (96766); Rieger 1893 OP (98230); Schierl 1899 BRNM (18808); Schierl 1899 PR (269524); Laus 1905 BRNU (413004); Laus 1906 BRNM (s.n.); Laus 1908 BRNU (28363); Laus 1910 PRC (s.n.); Thenius 1933 BRNM (251983); Thenius 1933 BRNU (332385); Šmarda 1946 BRNM (18802); Šmarda 1946 PR (P4S417/11053); Skřivánek 1946 BRNM (252020); Skřivánek 1955 BRNM (252031); Skřivánek 1955 BRNM (252010); Deyl 1965 OLM (153173); Burešovi, Jeník 1974 OLM (109648); Formánek s.d. BRNM (s.n.); Kolenati s.d. PR (P4S417/6889); Kamzičník: Oborny 1903 PRC (s.n.); Kvapilík 1936 OLM (92571, 92572, 92573); Skřivánek 1955 BRNM (252008, 252033, 252032, 252036); Velká kotlina: Bubela 1884 PRC (s.n.); Formánek s.d. BRNM (s.n.); Velký máj: Oborny 1879 BRNM (s.n.); Couka 1905 BRNU (413102); Laus 1924 OLM (68847); Skřivánek 1955 BRNM (252011); Při vodorovné cestě od Ovčárny ku Františkově myslivně: Juza 1909 BRNU (30809); Vysoká hole-Jelení hřbet: Čouka 1905 BRNU (413003); In pascuis elatis montis Wiesenberg infrequens: Freyn 1878 BRNM (s.n.); Hrubý Jeseník: Mükusch s. d. OP (12598).

Literature data: Fiek 1881: (ut H. alpinum L. d) eximium Backhouse:) im Gesenke auf der Brünnelhaide an den Felsen über der Kapelle selten (Gr., Bchm.), Altvater, Janowitzer Haide, Köpernik, Hockschar (W. Gr.). Oborny 1885: (ut H. eximium Backh.:) Zerstreut, meist truppweise [...] auf dem Höhenrücken des Gesenkes. Um die Tafelsteine, auf dem Maiberge, auf dem Altvater, um die Petersteine, Hohe Heide und um die Köperniksteine; auf dem Hochschar oberhalb der Kapelle auf der Brünnelheide, hier jedoch selten (G. \& Bm.) in einer kleinköpfigen Form auch am Abhange des Maiberges gegen den gr. Kessel. Oborny 1906: (ut H. eximium Backh.:) Zerstreut, meist truppweise [...] auf dem Kamme des Gesenkes über 1400 m, so auf der Hochschar, Köperniksteine, oberhalb der Kapelle auf der Brünnelheide in Felsspalten, auf dem Leiterberge, auf den Tafelsteinen und auf dem Altvater, Felsspalten der Petersteine, auf der hohen Heide, auf dem Heiligenhübel; in einer kleinköpfigen Form auch auf dem Maiberge, Abhang gegen den Neudorfer Kessel. Eine weitere Form wäre $\gamma$ tenellum G. Sch. sehr zart, schmalblättrig und einköpfig, diese auf der Brünnelheide, Hausberge (N.) und auf der hohen Heide hie und da. Skřivánek 1956: (ut H. nivimontis Oborny et Zahn:) společně s předchozím [Hieracium alpinum], nehojně, Svatá, Petrova skála 6. 8. 1955, Tabulové kameny 7. 8. 1955.

Chrtek (1995) elucidated complicated taxonomical treatment of Hieracium chrysostyloides and raised this taxon to species level. According to herbarium and literature data the species occurred at about nine localities scattered in the summit areas of the main HJM ridge. Although it is referred to grow above 1400 m a.s.l. (Oborny 1906, Chrtek 2004), localities Šerák, Vřesová studánka, Malý Děd and Velký Máj lie in lower altitudes - therefore the lowest altitudinal limit should be stated more precisely to be $1300 \mathrm{~m}$ a.s.l. Hieracium chrysostyloides has similar ecology as Hieracium alpinum (cf. Chrtek 2004) and the two species shared the same localities (Skrrivánek 1956, also see the lists of localities) but Hieracium chrysostyloides was apparently rarer. There has been no information about the condition of populations since the 1950s. J. Chrtek confirmed the species occurrence on Petrovy kameny in 1994 (Chrtek 1995) and later mentions that it probably occurs contemporarily in this locality only (Chrtek 2004).

\section{Current distribution in the HJM}

Table 5: Current localities of Hieracium chrysostyloides in the HJM

\begin{tabular}{|l|l|l|l|l|l|}
\hline Locality & GPS & Alt. & Date & Count & Herb. \\
\hline $\begin{array}{l}\text { Červená hora, outcrops on a summit alpine } \\
\text { grassland above Vřesová studánka, leg. J. Kocián }\end{array}$ & $\begin{array}{l}50^{\circ} 08^{\prime} 44.6^{\prime \prime} \mathrm{N} \\
17^{\circ} 08^{\prime} 09.3^{\prime \prime} \mathrm{E}\end{array}$ & 1320 & 15.7 .2008 & $10 \mathrm{fl}$. & NJM \\
\hline $\begin{array}{l}\text { Tabulové skály, alpine grassland on the rocks, leg. } \\
\text { J. Kocián }\end{array}$ & $\begin{array}{l}50^{\circ} 05^{\prime} 11.7^{\prime \prime} \mathrm{N} \\
17^{\circ} 13^{\prime} 52.0^{\prime \prime} \mathrm{E}\end{array}$ & 1455 & 1.8 .2012 & $2 \mathrm{fr}$. & NJM \\
\hline $\begin{array}{l}\text { Tabulové skály, alpine grassland on the rocks, not. } \\
\text { J. Kocián }\end{array}$ & $\begin{array}{l}50^{\circ} 05^{\prime} 11.7^{\prime \prime} \mathrm{N} \\
17^{\circ} 13^{\prime} 51.6^{\prime \prime} \mathrm{E}\end{array}$ & 1455 & 2.7 .2016 & $9 \mathrm{fl.}$ & - \\
\hline
\end{tabular}




\begin{tabular}{|c|c|c|c|c|c|}
\hline Locality & GPS & Alt. & Date & Count & Herb. \\
\hline $\begin{array}{l}\text { Tabulové skály, alpine grassland on the rocks, not. } \\
\text { J. Kocián }\end{array}$ & $\begin{array}{l}50^{\circ} 05^{\prime} 11.6^{\prime \prime} \mathrm{N} \\
17^{\circ} 13^{\prime} 51.8^{\prime \prime} \mathrm{E}\end{array}$ & 1455 & 2.7. 2016 & $1 \mathrm{fl}$. & - \\
\hline $\begin{array}{l}\text { Tabulové skály, alpine grassland on the rocks, not. } \\
\text { J. Kocián }\end{array}$ & $\begin{array}{l}50^{\circ} 05^{\prime} 11.5^{\prime \prime} \mathrm{N} \\
17^{\circ} 13^{\prime} 51.0^{\prime \prime} \mathrm{E}\end{array}$ & 1455 & 12. 7. 2015 & $1 \mathrm{fl}$. & - \\
\hline $\begin{array}{l}\text { Tabulové skály, alpine grassland on the rocks, not. } \\
\text { J. Kocián }\end{array}$ & $\begin{array}{l}50^{\circ} 05^{\prime} 11.1^{\prime \prime} \mathrm{N} \\
17^{\circ} 13^{\prime} 50.8^{\prime \prime} \mathrm{E}\end{array}$ & 1455 & 12. 7. 2015 & $1 \mathrm{fl}$. & - \\
\hline $\begin{array}{l}\text { Tabulové skály, alpine grassland on the rocks, not. } \\
\text { J. Kocián }\end{array}$ & $\begin{array}{l}50^{\circ} 05^{\prime} 10.9^{\prime \prime} \mathrm{N} \\
17^{\circ} 13^{\prime} 49.7^{\prime \prime} \mathrm{E}\end{array}$ & 1455 & 12. 7. 2015 & $1 \mathrm{fl}$. & - \\
\hline $\begin{array}{l}\text { Tabulové skály, small rocks by the path leading } \\
\text { from Praděd to Tabulové skály, not. J. Kocián }\end{array}$ & $\begin{array}{l}50^{\circ} 05^{\prime} 07.5^{\prime \prime} \mathrm{N} \\
17^{\circ} 13^{\prime} 49.7^{\prime \prime} \mathrm{E}\end{array}$ & 1460 & 12. 7. 2015 & $11 \mathrm{fl}$. & - \\
\hline $\begin{array}{l}\text { Praděd, alpine grassland } 190 \mathrm{~m} \text { N of the summit, } \\
\text { nearby the border stone, along the path to Praděd, } \\
\text { leg. J. Kocián }\end{array}$ & $\begin{array}{l}50^{\circ} 05^{\prime} 04.8^{\prime \prime} \mathrm{N} \\
17^{\circ} 13^{\prime} 54.3^{\prime \prime} \mathrm{E}\end{array}$ & 1480 & 9.7. 2006 & $\begin{array}{l}19 \mathrm{fl} . \\
(2015)\end{array}$ & NJM \\
\hline $\begin{array}{l}\text { Praděd, alpine grassland, } 100 \mathrm{~m} \mathrm{~N} \text { of the summit, } \\
\text { not. J. Kocián }\end{array}$ & $\begin{array}{l}50^{\circ} 05^{\prime} 02.3^{\prime \prime} \mathrm{N} \\
17^{\circ} 13^{\prime} 51.9^{\prime \prime} \mathrm{E}\end{array}$ & 1485 & 12. 7. 2015 & $22 \mathrm{fl}$. & - \\
\hline $\begin{array}{l}\text { Praděd, alpine grassland on the summit, } 80 \mathrm{~m} \mathrm{~W} \text { of } \\
\text { summit, not. J. Kocián }\end{array}$ & $\begin{array}{l}50^{\circ} 04^{\prime} 59.4^{\prime \prime} \mathrm{N} \\
17^{\circ} 13^{\prime} 47.3^{\prime \prime} \mathrm{E}\end{array}$ & 1485 & 12. 7. 2015 & $51 \mathrm{fl}$. & - \\
\hline $\begin{array}{l}\text { Praděd, alpine grassland nearby the unused path on } \\
\text { SW slope of the mountain, } 180 \mathrm{~m} \text { SWW of } \\
\text { the summit, not. J. Kocián }\end{array}$ & $\begin{array}{l}50^{\circ} 04^{\prime} 56.6^{\prime \prime} \mathrm{N} \\
17^{\circ} 13^{\prime} 44.3^{\prime \prime} \mathrm{E}\end{array}$ & 1480 & 12. 7. 2015 & $17 \mathrm{fl}$. & - \\
\hline $\begin{array}{l}\text { Petrovy kameny, alpine grassland between Petrovy } \\
\text { kameny and the chairlift upper exit, not. J. Kocián }\end{array}$ & $\begin{array}{l}50^{\circ} 04^{\prime} 07.2^{\prime \prime} \mathrm{N} \\
17^{\circ} 14^{\prime} 01.4^{\prime \prime} \mathrm{E}\end{array}$ & 1435 & 20.7 .2013 & $\begin{array}{l}85 \mathrm{fl} . \\
(2016)\end{array}$ & - \\
\hline $\begin{array}{l}\text { Vysoká hole, alpine grassland, by summit red tourist } \\
\text { path, leg. J. Kocián }\end{array}$ & $\begin{array}{l}50^{\circ} 03^{\prime} 53.3^{\prime \prime} \mathrm{N} \\
17^{\circ} 14^{\prime} 05.0^{\prime \prime} \mathrm{E}\end{array}$ & 1460 & 16. 7. 2008 & $10 \mathrm{fl}$. & NJM \\
\hline
\end{tabular}

We revised all historical localities of Hieracium chrysostyloides and ascertained its current occurrence on five of them. It grows together with Hieracium alpinum in all localities except for Červená hora. Populations on Červená hora, Tabulové skály and Vysoká hole are very small, the ones on Praděd and Petrovy kameny are relatively rich. All populations are very negatively influenced due to nibbling by herbivore mammals. For example, we have never seen flowering plants of Hieracium chrysostyloides on Vysoká hole since 2008, despite the plants were still present there in later years, but the flowering stems and partially also the leaves were always grazed. There is a similar situation on Praděd - there were 109 flowering plants in total on four sites on 12th July 2015 but all(!) flowering stems were grazed two weeks later. Thus, the seed production is usually completely thwarted. Moreover, the comparision of historical distribution with the recent one shows a decline in number of localities - from about nine to five. Hieracium chrysostyloides was probably exterminated by Pinus mugo Turra planting on Šerák and it could have been exterminated by intensive herbarium collecting on Kamzičník (and weakened on other localities, mainly on Vysoká hole and Červená hora - see Fig 9). It is necessary to pay maximal conservational attention to this pentaploid endemic. 

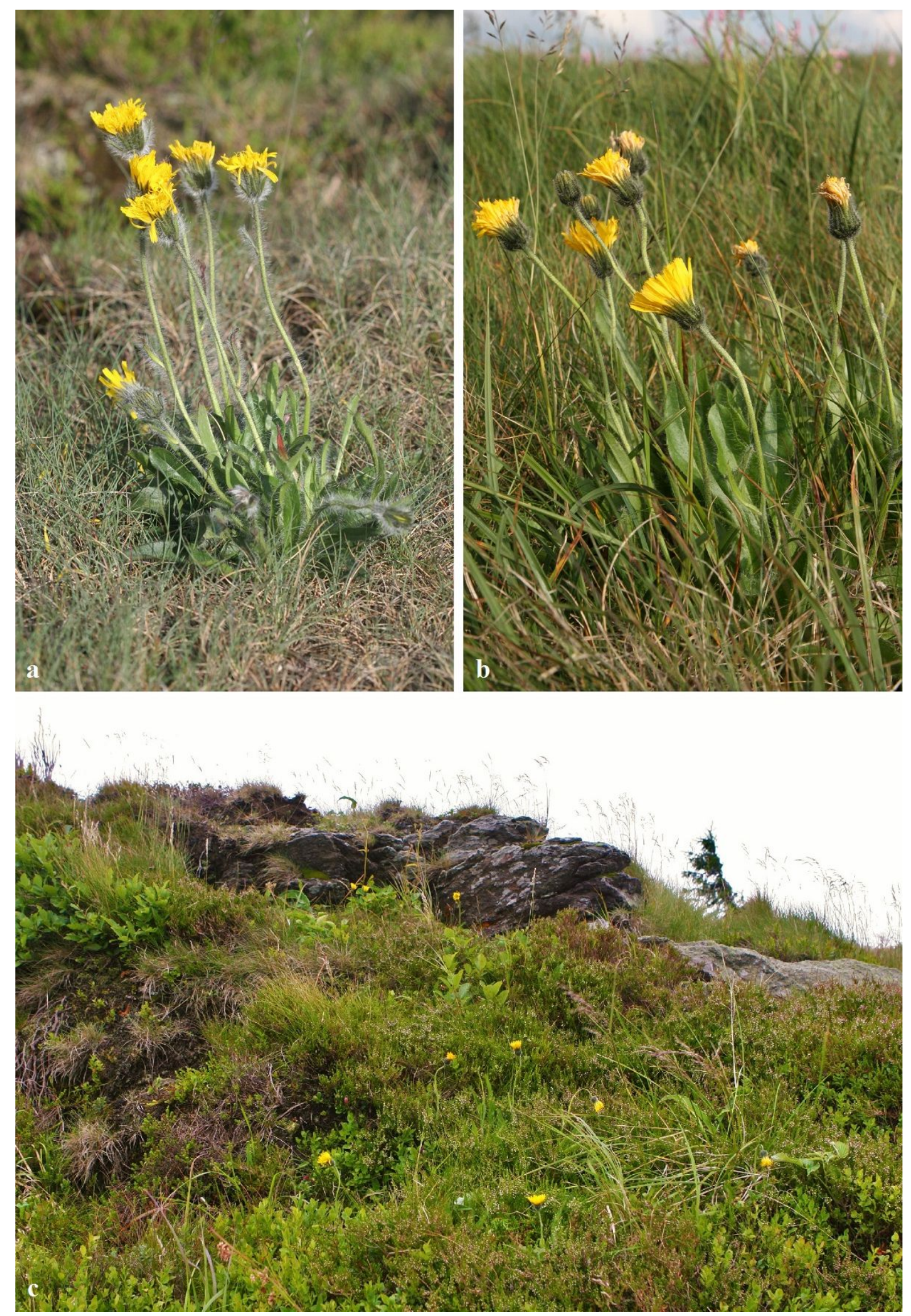

Fig 1: a - Hieracium alpinum on Praděd (9. VII. 2006), b - Hieracium chryostyloides on Vysoká hole (16.VII. 2008), c - Hieracium chrysostyloides population on Červená hora (15. VII. 2008). Photos Petr Kocián. 


\section{Hieracium engleri R. Uechtr.}

The range of Hieracium engleri comprises the Krkonoše Mts (a single locality - Mały Kocioł Śnieżny - on the Polish side of the mountain range), the HJM and the Tatry Mts (Zahn 1922-1938). In the Czech Republic it grows only in the HJM (Zahn 1.c.).

\section{Historical distribution in the HJM}

Herbarium specimens: Velká kotlina: Engler 1867 WRSL (s.n.); Freyn 1878 BRNM (s.n.); Ficinus 1883 WRSL (s.n.); Freyn 1883 BRNM (s.n., s.n.); Baenitz 1893 BRNM (s.n.); Fiek 1895 WRSL (s.n.); Oborny 1903 BRNM (s.n.); Weber 1932 PR (P4S417/10207\&324702); Šmarda 1946 BRNM (68260); Skřrivánek 1956 BRNM (252388); Danihelka 1996 BRNU (DA96/108); Hohes Gesenke: Freyn 1878 BRNM (s.n.).

Literature data: Fiek 1881: Steinige u. grasige Lehnen, Felsen des Hochgeb., sehr selten. Gr. Kessel des Gesenkes! (schon Gr.). Oborny 1885: Steinige und grasige Abhänge, sehr selten. Bisher nur am oberen Rande des gr. Kessels im mähr. Gesenke (Grabowsky, später Engler). Oborny 1906: Steinige und grasige Abhänge, sehr selten. Bisher nur im grossen Kessel u. z. am mittleren und unteren Rande desselben zerstreut, in der Nähe des Standortes von H. villosum. Skřivánek 1956: [not mentioned].

Hieracium engleri was discovered in Velká kotlina by A. Engler in 1867 (though confusingly Grabowsky is mentioned as the first collector of this species in later literature) and described from this locality by Uechtritz (1871). Velká kotlina is the only historically known locality of this species in the HJM and its occurrence was always reported as very rare. Chrtek (2004) states that Hieracium engleri was collected many times in the past (however, as shown above, only a few herbarium specimens exist) and that the contemporary population condition is not known and requires a revision. Although the species was collected a few times during the 20th century, these herbarium specimens were either wrongly determined or undetermined until our revision, so in fact nothing has been known about the species occurrence in the HJM for a century.

\section{Current distribution in HJM}

Table 6: Current localities of Hieracium engleri in the HJM

\begin{tabular}{|l|l|l|l|l|l|}
\hline Locality & GPS & Alt. & Date & Count & Herb. \\
\hline $\begin{array}{l}\text { Velká kotlina, scree in the upper part of Vitáskova } \\
\text { rokle, leg. J. Kocián (independently by Z. Kaplan in } \\
\text { 2013) }\end{array}$ & $\begin{array}{l}50^{\circ} 03^{\prime} 23.0^{\prime \prime N} \\
17^{\circ} 14^{\prime} 08.8^{\prime \prime} \mathrm{E}\end{array}$ & 1300 & 22.7 .2012 & $4 \mathrm{~T}$ fl. & BRNU \\
\hline $\begin{array}{l}\text { Velká kotlina, Mildeho skalka, N facing part of } \\
\text { the rock, not. J. Kocián }\end{array}$ & $\begin{array}{l}50^{\circ} 03^{\prime} 15,2^{\prime \prime N} \\
17^{\circ} 14^{\prime} 06,6^{\prime \prime} \mathrm{E}\end{array}$ & 1285 & 18.7 .2015 & $1 \mathrm{fl.}$ & - \\
\hline
\end{tabular}

We confirmed Hieracium engleri on two sites in Velká kotlina and actually rediscovered it in the HJM. The current population in Vitáskova rokle seems to be vital and although it grows in an unstable biotope of moving scree such permanent natural disturbation seems to be crucial for the species existence. We found only one flowering plant on the second site - on Mildeho skalka. It is possible that Hieracium engleri grows on more sites on the barely accessible rocks of Velká kotlina. In any case, the species is one of the rarest HJM hawkweeds and requires a high degree of conservational attention. 

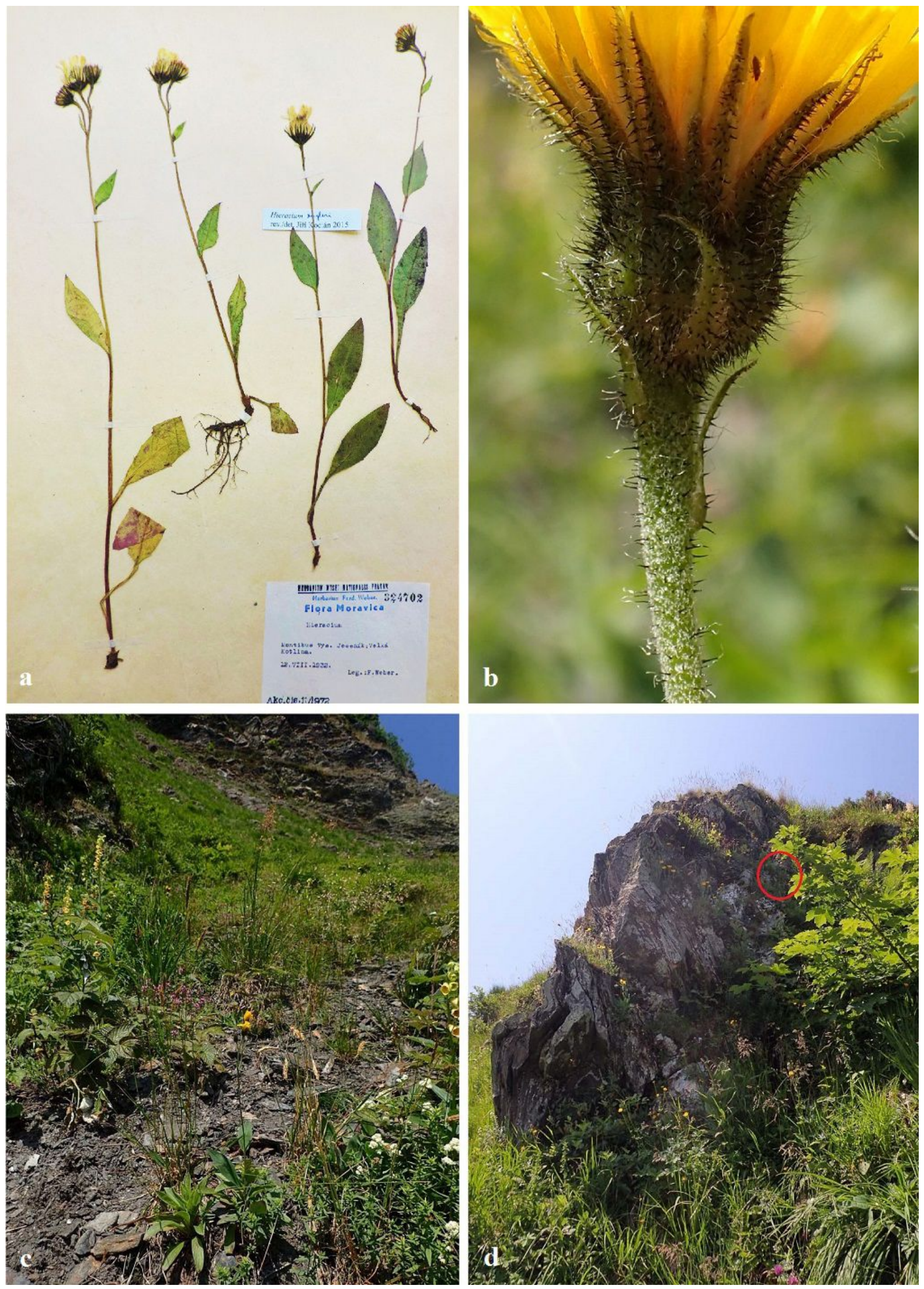

Fig 2: Hieracium engleri: a - herbarized plants showing typical habitus, $b$ - peduncle and involucre (10. VII. 2016), $\mathrm{c}$ - biotope in Vitáskova rokle (18. VII. 2015), d - site on Mildeho skalka in red circle (18. VII. 2015). Photos Jiř́ Kocián. 


\section{Hieracium grabowskianum Nägeli \& Peter}

The range of Hieracium grabowskianum is limited to the HJM and the Carpathian Mts (Zahn 1922-1938). In the Czech Republic it grows only in the HJM (Zahn 1.c.).

\section{Historical distribution in the HJM}

Herbarium specimens: Velká kotlina: Bittner 1895 BRNM (22130/36); Peter s.d. BRNM (22128/36, cultivated plant).

Literature data: Fiek 1881: Aeusserst selten unter den Eltern auf Felsplatten des gr. Kessels im Gesenke! (Gr., U.). Oborny 1885: Sehr selten, bisher nur auf Felsen und Felsplatten in der westlichen Abdachung des gr. Kessels im Mähr. Gesenke, oberhalb des Standortes von H. villosum. Oborny 1906: Sehr selten, bisher nur unter den Stammeltern auf Felsen in der westlichen Abdachung des grossen Kessels im Gesenke. Skřivánek 1956: [not mentioned].

Hieracium grabowskianum is the rarest HJM hawkweed. We found only two herbarium specimens of this species. The rarity of the species and its occurrence only in Velká kotlina is confirmed by the literature. Nothing has been known about its population condition for more than a century.

\section{Current distribution in the HJM}

Table 7: Current localities of Hieracium grabowskianum in the HJM

\begin{tabular}{|l|l|l|l|l|l|}
\hline Locality & GPS & Alt. & Date & Count & Herb. \\
\hline $\begin{array}{l}\text { Velká kotlina, Roemerovy výchozy, upper edge of } \\
\text { the rock, leg. J. Kocián }\end{array}$ & $\begin{array}{l}50^{\circ} 03^{\prime} 14.6^{\prime \prime} \mathrm{N} \\
17^{\circ} 14^{\prime} 08.5^{\prime \prime} \mathrm{E}\end{array}$ & 1255 & 20.7 .2013 & $2 \mathrm{fl}$. & BRNM \\
\hline
\end{tabular}
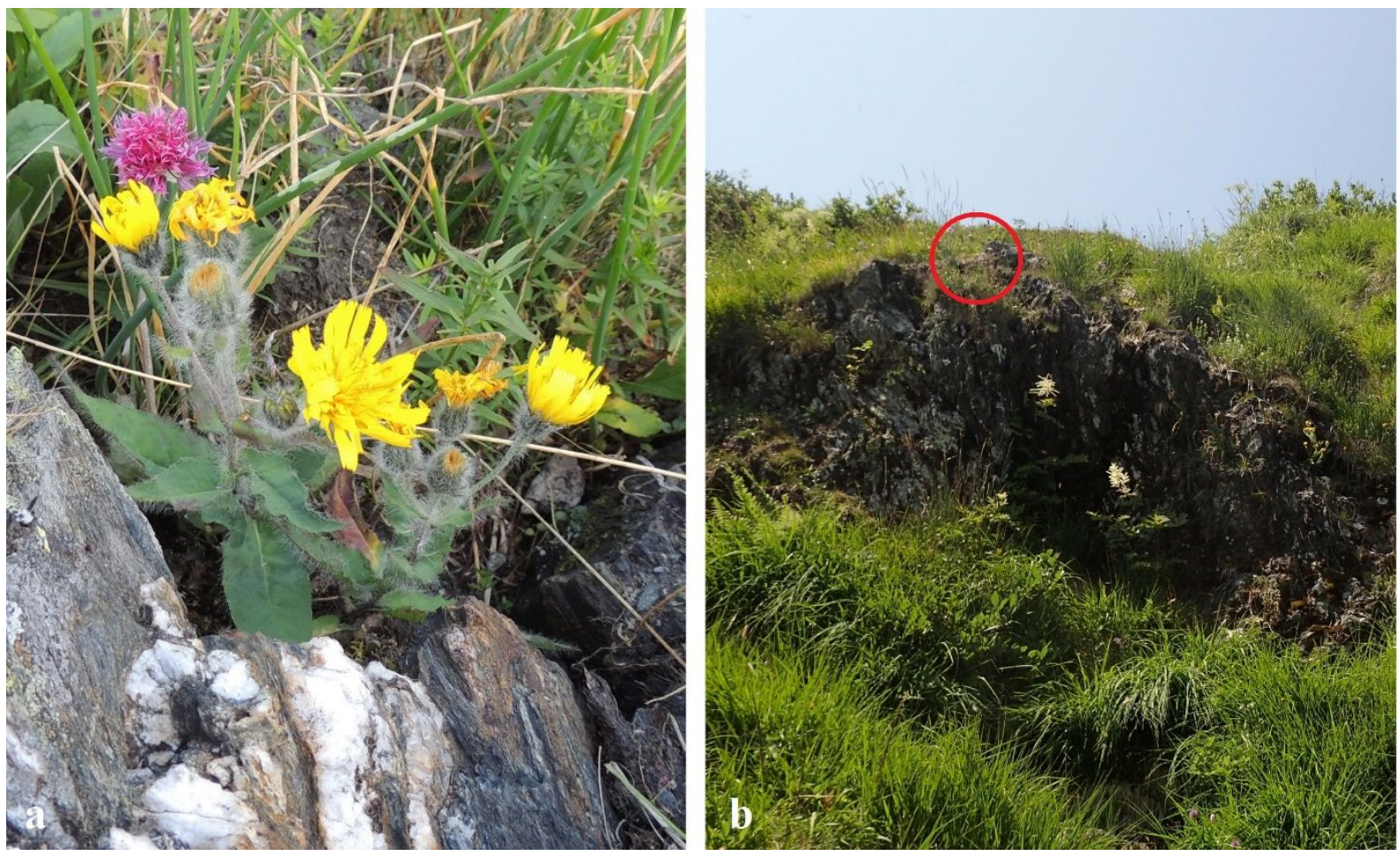

Fig 3: Hieracium grabowskianum: a - plant (20. VII. 2013), b - Roemerovy výchozy, the site of Hieracium grabowskianum in red circle (18. VII. 2015). Photos Jiří Kocián. 
We rediscovered Hieracium grabowskianum at a single locality on Roemerovy výchozy in Velká kotlina. It is probably the same site which was mentioned historically since the locality characteristics match those mentioned in literature: the plant grows on the rocks on the west slope of Velká kotlina and even both "parental species" Hieracium villosum and Hieracium prenanthoides are present there. Hieracium grabowskianum is truly very rare since only 1-3 flowering stems develop from probably a single rhizome. Despite this rarity the plant seems to be prosperous - it bloomed and fruited every year from 2013 to 2016.

On the basis of this rediscovery Hieracium grabowskianum can be stated not only as one of the rarest HJM plant species, but even as one of the rarest plant species in the whole Czech Republic.

\section{Hieracium inuloides agg.}

The range of Hieracium inuloides agg. is disjunctional and comprises mainly the mountains of Western, Northern and Central Europe (Zahn 1922-1938). In the Czech Republic it is reported from the Krkonoše Mts, Mt. Králický Sněžník and the HJM (Zahn l.c.).

\section{Historical distribution in the HJM}

Herbarium specimens: Hieracium inuloides agg. is a taxonomically unresolved aggregate species and therefore only the overview of herbarium localities is given: Šerák, Keprník, Vozka, Vřesová studánka (Červená hora), Praděd, Vatergraben, Mooselehne, Ovčárna, Petrovy kameny, Vysoká hole, Velká kotlina, Františkova myslivna, Velký máj, Malá kotlina, Pecny, Horizontalweg, Mentschik graben.

Literature data: Fiek 1881: (ut H. tauschianum a) inuloides:) im Gesenke am Altvater! (Gr.), Peterstein!, im gr. Kessel! (W. Fl.) u. bei Franzens Jagdhaus in der Kriech (Oborny)! (ut H. tauschianum a) inuloides $\beta$ striatum:) im Gesenke am Köpernikstein (Wkl.)!, auf der Brünnelhaide (Z.)!, im gr, Kessel! (U.), hier mit Uebergängen zur Grundform!; am Altvater eine niedrige 1-3köpfige Form mit sehr grossen bis $0,02 \mathrm{~m}$. breiten Hüllen! (ut $H$. tauschianum b) pachycephalum:) im Gesenke am Altvater!, Hirschkamm! (Freyn), an der Janowitzer Haide!, im gr. Kessel! (Gr.), kl. Kessel (Bchm.)!, in der Kriech bei Franzensjagdhaus (Oborny)! u. am Schlössel (Fr.)! Oborny 1885: (ut $H$. inuloides:) Südliche Abdachung des Altvaters, Oppaquellen, hier am häufigsten; seltener am Petersteine (Ue.), im gr. Kessel (W. Fl.), beim Franzensjagdhause, in der Kriech, hier in einer ziemlich stark grauflocken Modification; typisch auf dem Ameisenhügel bei Wiesenberg, hier nicht selten. (ut H. striatum:) im Hochgesenke: Köperniksteine (Winkler), Fuhrmannsteine, Brünnelheide, Horizontalweg zwischen dem Franzensjagdhause und dem Petersteine; auf dem Altvater eine 1-3köpfige, niedrige Form mit sehr grossen Hüllen, üeberdies noch am grossen Hirschkamm und im kleinen Kessel (Freyn). (ut H. pachycephalum:) im Hochgesenke zerstreut: Altvater und zwar Abdachung gegen die Oppa-Quellen; Hirschbrunnen, Horizontalweg, Franzensjagdhaus; am Schlössel (Fritze) und am Ameisenhügel. In einer stylosen Form nicht selten, und zwar im gr. und kl. Kessel und am Wege von da zum Jagdhause. Oborny 1906: (ut H. inuloides Tsch.:) Auf der südlichen Abdachung des Altvaters gegen die Oppaquellen, hier am häufigsten, seltener um die Petersteine (Ue.), im grossen und kleinen Kessel, beim Franzens-Jagdhause, in der Kriech, au dem Ameisenhügel und als Seltenheit auf der Brünnelheide. (ut ssp. pseudostriatum Z.:) Hochschar, Abdachung unterhalb des Gerog-Schutzhauses, um die Köperniksteine (Winkler), Fuhrmannsteine, Brünnelheide, Altvater, Abhang gegen die Oppaquelen, KleinMohrauer Gebirgsweb, grosser und kleiner Kessel, Horizontalweg zwischen dem Franzens-Jagdhause und den Petersteinen, auf den Abhängen des Maiberges gegen das Jabdhaus. [...] Fuhrmansteine [...] Brünnelheide, Schäferei, Oppaquellen, grosser Kessel, Maiberg, Abhang gegen Franzens-Jagdhaus. [...] in einem Schlage oberhalb des Drei steines bei Goldenstein. (ut ssp. corymbosum Fr. in litt. ad Vulp.:) Horizontalwege beim Franzens-Jagdhause [...] Karlsdorf am Waldessaume hinter den Olbrichhäusern bei $800 \mathrm{~m}$ Seehöhe. (ut H. striatum Tsch.:) Brünnelheide, Fuhrmannsteine, Altvater, Abdachung gegen die Oppaquellen, Hirschbrunnen, Janowitzer Heide, grosser und kleiner Kessel, Hirschkamm, Horizontalweg zwischen dem Franzens-Jagdhause und den Petersteinen, am Schlössel (Fritze), am Ameisenhügel. Zuweilen tief herabgehend, so bei $1000 \mathrm{~m}$ im oberen Marchthale bei Gr.-Mohrau. Skřivánek 1956: (ut $H$. inuloides:) na horských nivách společně s předchozími $[H$. prenanthoides and H. lanceolatum]. Velký kotel, Praděd 4. 8. 1946, Vysoká hole 4. 8. 1953, Malý kotel 5. 8. 1953. (ut H. striatum:) horské nivy, dosti častý. Velký kotel, Praděd 4. 8. 1946, Vysoká hole 4. 8. 1953, Malý kotel 5. 8. 1953. 
Current distribution in the HJM

Table 8: Current localities of the Hieracium inuloides agg. in the HJM

\begin{tabular}{|c|c|c|c|c|c|}
\hline Locality & GPS & Alt. & Date & Count & Herb. \\
\hline $\begin{array}{l}\text { Ovčárna, mountain meadow above Ovčárna chalet, } \\
\text { leg. J. Kocián }\end{array}$ & $\begin{array}{l}50^{\circ} 04^{\prime} 14.1^{\prime \prime} \mathrm{N} \\
17^{\circ} 14^{\prime} 20.2^{\prime \prime} \mathrm{E}\end{array}$ & 1300 & 19. 8. 2010 & $15 \mathrm{fl}$. & KOC \\
\hline $\begin{array}{l}\text { Velká kotlina, upper north part of subalpine tall } \\
\text { grassland under Wilschowitzovy výchozy, leg. } \\
\text { J. Kocián }\end{array}$ & $\begin{array}{l}50^{\circ} 03^{\prime} 29.0^{\prime \prime} \mathrm{N} \\
17^{\circ} 14^{\prime} 18.0^{\prime \prime} \mathrm{E}\end{array}$ & 1300 & 5.8 .2012 & $28 \mathrm{fl}$. & KOC \\
\hline $\begin{array}{l}\text { Velká kotlina, Kratochvílova stráň, Molinia } \\
\text { grassland, not. J. Kocián }\end{array}$ & $\begin{array}{l}50^{\circ} 03^{\prime} 27.6^{\prime \prime} \mathrm{N} \\
17^{\circ} 14^{\prime} 16.9^{\prime \prime} \mathrm{E}\end{array}$ & 1285 & 15.8 .2015 & $3 \mathrm{fl}$. & - \\
\hline $\begin{array}{l}\text { Velká kotlina, small rock } 50 \mathrm{~m} \mathrm{NE} \text { of Kettnerova } \\
\text { skála, not. J. Kocián }\end{array}$ & $\begin{array}{l}50^{\circ} 03^{\prime} 26.6^{\prime \prime} \mathrm{N} \\
17^{\circ} 14^{\prime} 10.8^{\prime \prime} \mathrm{E}\end{array}$ & 1315 & 5. 8. 2012 & $1 \mathrm{fl}$. & - \\
\hline $\begin{array}{l}\text { Velká kotlina, Kolenatiho skály, vegetation with } \\
\text { grasses, dwarf bushes and ferns under small rock, } \\
\text { not. J. Kocián }\end{array}$ & $\begin{array}{l}50^{\circ} 03^{\prime} 25.8^{\prime \prime} \mathrm{N} \\
17^{\circ} 14^{\prime} 12.5^{\prime \prime} \mathrm{E}\end{array}$ & 1295 & 23.7 .2016 & $2 \mathrm{fl}$. & - \\
\hline $\begin{array}{l}\text { Velká kotlina, subalpine tall grassland SW of } \\
\text { Vitáskova rokle, above the path crossing the ravine, } \\
\text { two close micropopulations, not. J. Kocián }\end{array}$ & $\begin{array}{l}50^{\circ} 03^{\prime} 21.7^{\prime \prime} \mathrm{N} \\
17^{\circ} 14^{\prime} 07.2^{\prime \prime} \mathrm{E}\end{array}$ & 1330 & 22.7 .2012 & $2+3 \mathrm{fl}$ & - \\
\hline $\begin{array}{l}\text { Velká kotlina, Molinia grassland under Suzova } \\
\text { stěna, leg. J. Kocián }\end{array}$ & $\begin{array}{l}50^{\circ} 03^{\prime} 17.5^{\prime \prime} \mathrm{N} \\
17^{\circ} 14^{\prime} 12.1^{\prime \prime} \mathrm{E}\end{array}$ & 1205 & 31.7 .2012 & $12 \mathrm{fl}$. & KOC \\
\hline $\begin{array}{l}\text { Velká kotlina, S edge of Fiekovy ohlazy, grassland, } \\
\text { not. J. Kocián }\end{array}$ & $\begin{array}{l}50^{\circ} 03^{\prime} 16.8^{\prime \prime} \mathrm{N} \\
17^{\circ} 14^{\prime} 03.5^{\prime \prime} \mathrm{E}\end{array}$ & 1335 & 5. 8.2012 & $1 \mathrm{fl}$. & - \\
\hline $\begin{array}{l}\text { Velká kotlina, Fiekovy ohlazy, small grassy rock } \\
\text { with small Salix bushes, not. J. Kocián }\end{array}$ & $\begin{array}{l}50^{\circ} 03^{\prime} 16.3^{\prime \prime} \mathrm{N} \\
17^{\circ} 14^{\prime} 05.1^{\prime \prime} \mathrm{E}\end{array}$ & 1310 & 23.7 .2016 & $1 \mathrm{fl}$. & - \\
\hline $\begin{array}{l}\text { Velká kotlina, NW edge of Otrubova strán̆, steep } \\
\text { slope (ferns, grasses, blueberry bushes), not. } \\
\text { J. Kocián }\end{array}$ & $\begin{array}{l}50^{\circ} 03^{\prime} 15.7^{\prime \prime} \mathrm{N} \\
17^{\circ} 14^{\prime} 09.5^{\prime \prime} \mathrm{E}\end{array}$ & 1240 & 20.7 .2013 & rare & - \\
\hline $\begin{array}{l}\text { Velká kotlina, south edge of Fiekovy ohlazy, grassy } \\
\text { slope, not. J. Kocián }\end{array}$ & $\begin{array}{l}50^{\circ} 03^{\prime} 15.4^{\prime \prime} \mathrm{N} \\
17^{\circ} 14^{\prime} 04.8^{\prime \prime} \mathrm{E} \\
\end{array}$ & 1310 & 23.7 .2016 & $2 \mathrm{fl}$. & - \\
\hline \begin{tabular}{|l|} 
Velká kotlina, subalpine tall grassland above \\
Roemerovy výchozy, not. J. Kocián
\end{tabular} & $\begin{array}{l}50^{\circ} 03^{\prime} 15.0^{\prime \prime} \mathrm{N} \\
17^{\circ} 14^{\prime} 07.3^{\prime \prime} \mathrm{E} \\
\end{array}$ & 1275 & 29.8. 2015 & $7 \mathrm{fl}$. & - \\
\hline $\begin{array}{l}\text { Velká kotlina, grassy slope south of Fiekovy ohlazy, } \\
\text { not. J. Kocián }\end{array}$ & $\begin{array}{l}50^{\circ} 03^{\prime} 14.9^{\prime \prime} \mathrm{N} \\
17^{\circ} 14^{\prime} 05.6^{\prime \prime} \mathrm{E}\end{array}$ & 1295 & 23.7 .2016 & $2 \mathrm{fl}$. & - \\
\hline
\end{tabular}

Although the Hieracium inuloides agg. grew scattered on many localities throughout whole HJM in the past, today we only find it in two localities: in Velká kotlina (several sites) and on a single site above the Ovčárna chalet. Most populations are small and the upper parts of flowering stems are usually nibbled. Hieracium inuloides agg. shows the highest decline of localities and also the greatest relative difference between the number of herbarised plants and plants remaining in nature from all HJM Hieracium species (see Fig 9). The causes of this situation are unclear.

The Hieracium inuloides agg., like the Hieracium prenanthoides agg., is a taxonomically unresolved aggregate species. Taxonomical research is required to elucidate its diversity and variability - even endemic HJM microspecies are likely to be revealed. 


\section{Hieracium mixtum Froel.}

The natural range of this species comprises the Pyrenees and the Cantabrian Mountains where it grows on the rocks and steep slopes on calcareous shallow soils (Mateo 2007). It is a neophyte in the Czech Republic discovered in a sole locality in the HJM (Kocián \& Chrtek 2011).

\section{Historical distribution in the HJM}

We found Hieracium mixtum in the HJM in 2006 on a stony ditchy slope along the road to Praděd nearby the Kurzovní mountain hotel. The finding was already published together with the species' description, ecology, further information about the Praděd locality and hypothesis about its origin (almost certainly intentional planting or sowing; Kocián \& Chrtek 2011).

\section{Current distribution in the HJM}

Table 9: Current localities of Hieracium mixtum in the HJM

\begin{tabular}{|l|l|l|l|l|l|}
\hline Locality & GPS & Alt. & Date & Count & Herb. \\
\hline Ž́rový vrch, summit rock, leg. R. Štencl & $\begin{array}{l}50^{\circ} 06^{\prime} 31.3^{\prime \prime N} \\
17^{\circ} 18^{\prime} 38.3^{\prime \prime} \mathrm{E}\end{array}$ & 1090 & 2013 & unk. & BRNU \\
\hline $\begin{array}{l}\text { Praděd, S slope, stony ruin of former chalet, 350 m } \\
\text { SSE of altitudinal point 1356 and 900 m E of } \\
\text { Barborka chalet, not. R. Štencl }\end{array}$ & $\begin{array}{l}50^{\circ} 04^{\prime} 42.1^{\prime \prime N} \\
17^{\circ} 14^{\prime} 38.6^{\prime \prime} \mathrm{E}\end{array}$ & 1280 & 22.8 .2016 & $1 \mathrm{fr}$. & - \\
\hline $\begin{array}{l}\text { Praděd, stony ditchy slope along the road to Praděd, } \\
200 \mathrm{~m} \text { NW of Kurzovní mountain hotel, leg. J. Kocián }\end{array}$ & $\begin{array}{l}50^{\circ} 04^{\prime} 38.1^{\prime \prime} \mathrm{N} \\
17^{\circ} 13^{\prime} 24.5^{\prime \prime} \mathrm{E}\end{array}$ & 1355 & 9.7 .2006 & $2 \mathrm{fl.}$ & NJM \\
\hline
\end{tabular}
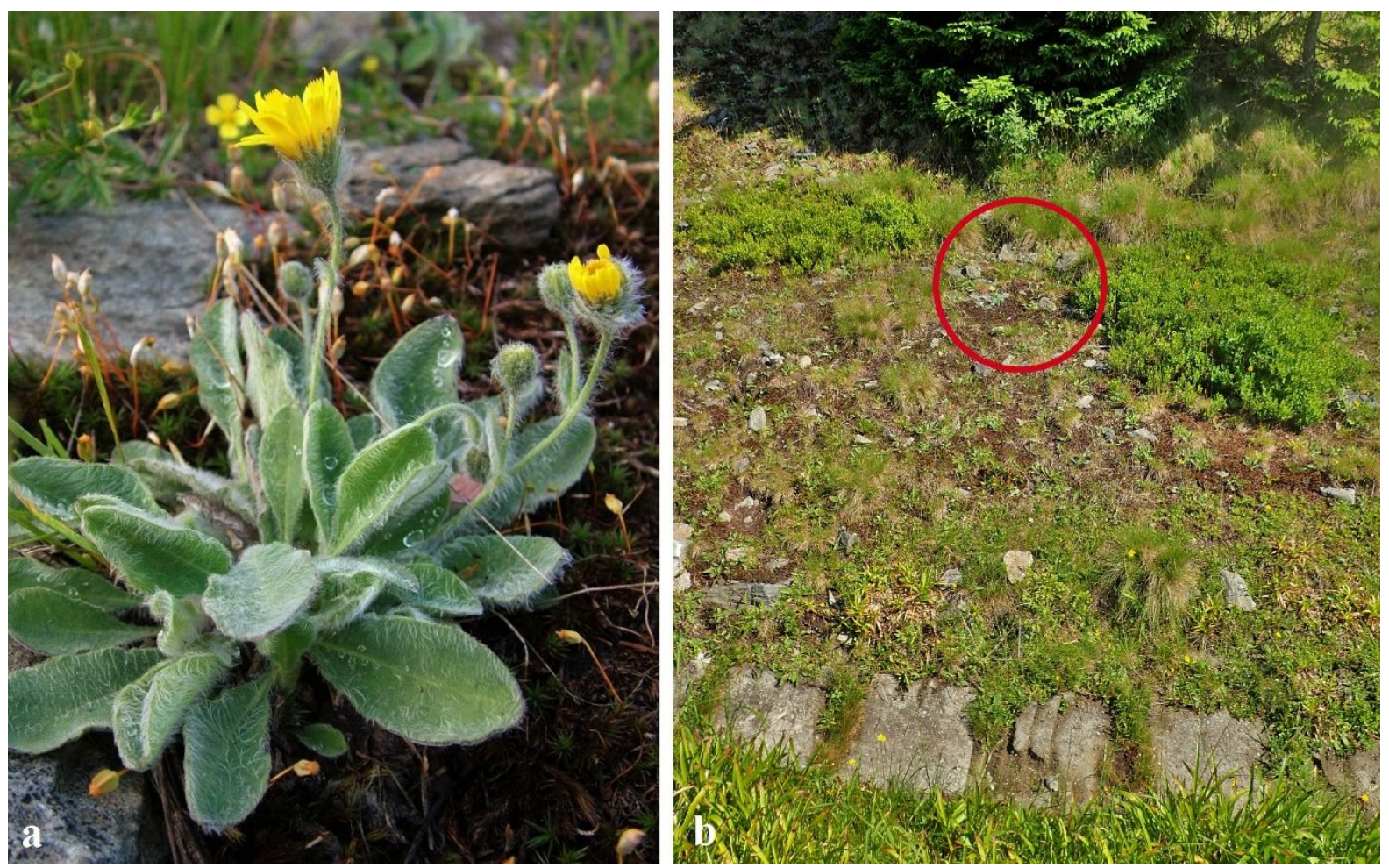

Fig 4: Hieracium mixtum: a - original cluster mother plant on the Praděd locality (9. VII. 2006), b - locality of Hieracium mixtum on Praděd, site of the plants in red circle (2. VII. 2016). Photo a Petr Kocián, photo b Jiř́ Kocián. 
After the discovery of the Praděd locality of Hieracium mixtum, R. Štencl found another one on Žárový vrch in 2013 and another locality on Praděd in 2016. The population on Praděd stagnates. The original cluster mother plant persists on the locality, blooms every year and slowly ramifies. The number of juvenile plants in 2012 (five) was the same as in 2010 and 2011. All localities originated undoubtely via intentional planting or sowing. After eleven-years of monitoring in the Praděd locality it is possible to state that the species does not have a tendency to spread to surrounding areas.

\section{Hieracium moravicum Oborny}

Hieracium moravicum is endemic to the HJM and the Western Carpathians (Zahn 19221938). In the Czech Republic it grows only in the HJM (Zahn 1.c.).

\section{Historical distribution in the HJM}

Literature data: Fiek 1881: (very probably ut $H$. albinum Fr.:) Im gr. Kessel des Gesenkes (Bchm.). Oborny 1885: Grasige und steinige Abhänge, ziemlich selten und nur im Hochgesenke. Im gr. Kessel den Standort mit H. Engleri und H. silesiacum theilend und sonst am oberen Rande des Kessels zerstreut; Franzens Jagdhaus und häufig im Kiesgraben (Ficinus), am Horizontalwege zwischen dem Petersteine und dem Jagdhause, beim Petersteine, Abhang des Altvaters gegen die Schweizerei; seltener auf dem Hochschar (Bl.) und auf dem Schlosskamme bei Annaberg. Oborny 1906: Im Verlaufe des Hochgesenkes auf der Hochschar, bei der Johannishütte, um die Fuhrmannsteine, Brünnelheide, Altvater, Petersteine, beim Franzens-Jagdhause, Hirschbrunnen, Maiberg, grosser und kleiner Kessel, schwarze Koppe bei Klein-Mohrau, Klein-Mohrauer Gebirgsweg, am Horizontalwege zwischen dem Franzens-Jagdhause und den Petersteinen, bei der Alfredshütte bei Altendorf, wilder Steingraben bei Winklersdorf; hi und da tief in die Thäler herabgehend, so bei Karlsdorf noch etwa bei $800 \mathrm{~m}$. Skřrivánek 1956: endemický typ Jeseníků, svahy Petrovy skály k Ovčárně 3. 8. 1953, Velký Kotel 4. 8. 1953, nehojně.

Oborny $(1885,1906)$ reported Hieracium moravicum from many HJM localities, however, Skrrivánek (1956) notes that the species is not abundant and comes from only two localities.

$H$. moravicum is the only species we did not find in the HJM during our field revision but it could have been neglected. Since the taxonomical value of this species is unclear it requires further study.

\section{Hieracium nigritum $\mathrm{R}$. Uechtr.}

The range of Hieracium nigritum comprises the highest Sudeten and Carpathian mountains and one locality in the Alps (Zahn 1922-1938). In the Czech Republic it grows in the Krkonoše Mts, Mt. Králický Sněžník and the HJM (Zahn 1.c.).

\section{Historical distribution in the HJM}

Herbarium specimens: Šerák: Baenitz 1893 BRNM (225676); Baenitz 1893 PR (s.n.); Oborny 1895 PR (s.n.); Teuber 1903 BRNM (19211); Laus 1906 BRNU (28470); Schenk 1929 BRNM (19209); s.coll. 1931 BRNM (19210); Zav̌rel 1947 BRNM (252338); Skřivánek 1956 BRNM (252342); Keprník: Oborny 1879 PRC (s.n.); Winkler 1879 BRNM (22567?); Bubela 1883 PR (P4S417/10705); Bubela 1884 PRC (s.n.); Formánek 1884 BRNM (225671); Oborny 1893 PRC (s.n.); Oborny 1895 PRC (s.n.); Oborny 1896 BRNU (04211, 44336); Teuber 1903 BRNM (19212); Laus 1908 BRNU (44331); Oborny 1908 PR (s.n.); Horák 1947 MP (54393, 54394); Skřivánek 1956 BRNM (252346); Schustler s.d. PR (s.n.); Vozka: Winkler 1879 WRSL (s.n.); Formánek 1884 BRNM (225672); Laus 1904 BRNU (206720); Laus 1904-5 BRNU (413105); Laus 1905 BRNU (28468); Skřivánek 1956 BRNM (252343); Schustler s.d. PR (s.n.); Knížecí chata: Oborny 1896 BRNM (225675); Vřesová studánka (Červená hora): Oborny 1886 BRNU (46341); Šmarda 1949 BRNM (19208); Skřivánek 1956 BRNM (252389); Oborny s.d. PR (s.n.); Schustler s.d. PR (s.n.); Königskoppe: Freyn 1883 BRNM (225704); Švýcárna: Baenitz 1893 PRC (s.n.); Baenitz 1893 WRSL (s.n.); Oborny 1908 OLM (102959); Skřrivánek 1955 BRNM (252337); Malý děd: Bubela 1883 PRC (s.n.); Freyn 1883 BRNM (225703); Praděd: Fiek 1870 WRSL (s.n.); Winkler 1879 WRSL (s.n.); Ficinus 1883 WRSL (s.n.); Freyn 1883 BRNM (225706); Spitzner 1887 BRNU 
(377368); Spitzner 1888 BRNU (195430); Andres 1893 PR (269715); Oborny 1900 BRNM (225696); Hofmann 1901 PR (s.n.); Laus 1910 BRNU (44329); Laus 1910 OP (20335); [Horák] 1930 MP (54395); Skřivánek 1946 BRNM (252340); Sut’: Freyn1883 BRNM (225712); Mravenečník: Oborny 1879 BRNU (64344); Oborny 1879 PRC (s.n.); Petrovy kameny: Freyn 1878 BRNM (225701, 225702, 225715); Laus 1904 BRNM (22569?); Laus 1905 BRNU (44334); Teuber 1905 BRNM (252349); Laus 1907 OLM (69258); Laus 1907 BRNU (44330); Laus 1908 BRNM (225692); Laus 1908 BRNU (413103); Laus 1908 PR (s.n.); Laus 1928 PRC (s.n.); Zavřel 1950 BRNM (252351); Schustler s.d. PR (s.n.); Malá Jezerná: Šmarda 1947 BRNM (66586); Kleine Heide: Freyn 1878 BRNM (225708, 225710, 225711); Vysoká hole: Oborny 1876 BRNU (64342); Oborny 1879 BRNM (225687); Freyn 1883 BRNM (225713, 225716); Freyn 1883 PRC (s.n., s.n.); Schierl 1886 PR (s.n.); Hora 1889 PRC (s.n.); Laus 1904 BRNU (28466, 413107); Laus 1905 BRNU (44333); Laus 1906 BRNU (413104); Laus 1908 BRNM (225691); Laus 1908 BRNU (s.n.); Hruby 1909 BRNU (162837); Laus 1930 OLM (69256); Thenius 1933 BRNM (252359); Thenius 1933 BRNU (332403, 332389, 332400); Dvořák 1946 OP (86754); Skřivánek 1946 BRNM (252344); Skřivánek 1946 MP (28941); Skřivánek 1946 PR (269713); Šmarda 1946 BRNM (252341); Skřivánek 1953 BRNM (252348); s. coll. s.d. BRNM (225686); Velká kotlina: Freyn 1878 BRNM (225709); Freyn 1883 BRNM (225714); Bubela 1884 PRC (s.n.); Spitzner 1888 BRNU (195431); Spitzner 1889 BRNU (351941); Oborny 1892 WRSL (s.n.); Oborny 1903 BRNM (225694); Oborny 1903 BRNU (64340); Oborny 1903 PRC (s.n.); Souček 1930 MP (28934); Souček 1930 PRC (s.n.); Otruba 1933 OLM (69262, 69261); Šourek 1946 PR (269499); Skřivánek 1956 BRNM (252347); Kamzičník: Skřivánek 1955 BRNM (252352); Františkova myslivna: Oborny 1886 PR (s.n.); Laus 1905 BRNU (28467); Jelení hřbet: Freyn 1878 BRNM (225680, s.n.); Skřivánek 1946 BRNM (252350); Skřivánek 1946 BRNU (360979, 572993); Šmarda 1947 BRNM (19204, 19206); Malá kotlina: Freyn 1878 BRNM (225699, 2256??); Velký máj: Oborny 1879 PR (s.n.); Oborny 1879 WRSL (s.n.); Oborny 1893 PRC (s.n.); Čouka 1905 BRNU (413102); Laus 1924 OLM (68847); Skřivánek 1955 BRNM (252354); Pecny: Oborny 1882 PRC (s.n.); Formánek 1886 BRNM (225679); am Wege vom Jagdhaus zum Maiberg: Oborny 1904 PRC (s.n.); Triften am Wiesenberg 1350 m: Freyn 1878 PR (s.n.); In pascuis montis Wiesenberg: Freyn 1878 BRNM (225680, 225681, 22570?; s.n.); Waldrand bei Gabelkreuz ob. Waldenburg: Freyn 1883 BRNM (225700); Steinberg oben Altendorf: Freyn 1878 BRNM (22568?); Peterswald-Wiesenberg: Oborny 1895 BRNM (225688); Triften der Abhänge unter ?. Vaterbaude gegen das Oppathal: Freyn 1883 BRNM (225707); Zwischen Köpenik u. Hockschar: Baenitz 1893 BRNM (225677).

Literature data: Fiek 1881: Wiesen u. grasige Lehnen des Hochgeb. Im Gesenke nicht selten: Fuhrmannsstein (Bchm.), Köpernikstein (Wkl.), Hockschar (O. Reinhardt), Hungerlehne (U.), Altvater! (U.), Peterstein (U.), kl. Haide (Bchm.), im gr.! (U.) u. kl. Kessel (Freyn), Schieferhaide, Ameisenhügel (Oborny), grosser Hirschkamm, Wiesenberg u. Steinberg über Altendorf (ders.). Oborny 1885: Grasige und steinige Lehnen und Abhänge in den Sudeten, stellenweise massenhaft und weit häufiger als alle übrigen Habichtskräuter. Im Gesenke längs des ganzen Zuges am Hochschar, Köpernik, am Fuhrmannsteine, auf der Brünnelheide, auf dem Altvater und auf der Hungerlehne (Ue.), Petersteine, hohe Heide, im gr. und kl. Kessel, Maiberg, Horizontalweg zwischen dem Petersteine und dem Jagdhause, auf dem Ameisenhügel, am gr. Hirschkamm, auf der Schieferheide und von da über die Backofensteine bis zu den verlorenen Steinen oberhalb Kleppel; auf dem Wiesen- und Steinberge bei Altendorf (Freyn). Oborny 1906: Grasige und steinige Lehnen und Abhänge am Spiglitzer Schneeberge und im Gesenke häufig. Im Gesenke längs des ganzen Kammes und auf dessen Abhängen, so auf dem Saalwiesenrücken, der Hochschaar. Peterswalder Wiesenberg, Köpernik, Fuhrmannstein, Brünnelheide, Hausberg, Altvater, Hungerlehne, Petersteine, hohe Heide, Maiberg, Ameisenhügel, im grossen und kleinen Kessel, am Horizontalwege zwischen dem Franzens-Jagdhause und den Petersteinen, am grossen Hirschkamm, Schieferheide und von da über die Backofensteine bis zu den verlorenen Steinen, wie auch auf dem Wiesen- und Steinberge bei Altendorf, auf der schwarzen Koppe bei Kl.-Mohrau, oft auch tief in die Thäler gehend und noch bei $1000 \mathrm{~m}$ nicht selten anzutreffen. $\beta$ eriocline Borb.: Grosser Kessel, Maiweise bei Karlsdorf, Hochschar. Skřrivánek 1956: sudetsko-karpatský druh, mající právě v Jeseníkách svá nejbohatší naleziště. Častý jak na horských holích, tak i na horských nivách, ojediněle i v nižších polohách. Při cestě od Švýcárny do Kout 29. 6. 1946, Praděd 29. 6. 1946 a 7. 8. 1955, Břidličná 5. 8. 1946, Vysoká hole 4. 8. 1946 a 6. 8. 1955, Svatá, Máj, Petrova skála 6. 8. 1955, Jelení hřbet 7. 8. 1955, Velký kotel 9. 8. 1955.

Hieracium nigritum is historically one of the most widespread HJM mountain hawkweed species. Both herbarium and literature records provide a long list of localities encompassing the whole HJM main ridge from Šerák to Pecny. The species had to grow in large numbers in the HJM - for example Skřivánek's herbarium specimens contain tens of plants from many localities. 


\section{Current distribution in the HJM}

Table 10: Current localities of Hieracium nigritum in the HJM

\begin{tabular}{|c|c|c|c|c|c|}
\hline Locality & GPS & Alt. & Date & Count & Herb. \\
\hline $\begin{array}{l}\text { Šerák, scree partially covered by soil } 20 \mathrm{~m} \text { under } \\
\text { belfry, } 100 \mathrm{~m} \text { SSE of Jiřího chalet, leg. J. Kocián }\end{array}$ & $\begin{array}{l}50^{\circ} 11^{\prime} 11.2^{\prime \prime} \mathrm{N} \\
17^{\circ} 06^{\prime} 33.6^{\prime \prime} \mathrm{E}\end{array}$ & 1315 & 8. 7. 2015 & $6 \mathrm{fl}$. & BRNU \\
\hline $\begin{array}{l}\text { Šrák, alpine grassland on the edge of the tourist } \\
\text { path } 60 \mathrm{~m} \text { SSE of the belfry ( } 14 \mathrm{fl} . \text { ) and along the } \\
\text { path towards it ( } 7 \mathrm{fl} \text {.), not. J. Kocián }\end{array}$ & $\begin{array}{l}50^{\circ} 11^{\prime} 09.8^{\prime \prime} \mathrm{N} \\
17^{\circ} 066^{\prime} 32.7^{\prime \prime} \mathrm{E}\end{array}$ & 1320 & 8. 7. 2015 & $21 \mathrm{fl}$. & - \\
\hline $\begin{array}{l}\text { Šerák, alpine grassland on the edge of the tourist path, } \\
50 \mathrm{~m} \text { NE of touristic signpost "Šerák - rozc.", not. } \\
\text { J. Kocián }\end{array}$ & $\begin{array}{l}50^{\circ} 11^{\prime} 05.3^{\prime \prime} \mathrm{N} \\
17^{\circ} 06^{\prime} 35.6^{\prime \prime} \mathrm{E}\end{array}$ & 1305 & 8.7.2015 & $2 \mathrm{fl}$. & - \\
\hline $\begin{array}{l}\text { Keprník, alpine grassland on the edge of the tourist } \\
\text { path to Keprník on the N slope of the mountain, not. } \\
\text { J. Kocián }\end{array}$ & $\begin{array}{l}50^{\circ} 10^{\prime} 59.4 " \mathrm{~N} \\
17^{\circ} 06^{\prime} 40.7^{\prime \prime} \mathrm{E}\end{array}$ & 1300 & 8. 7.2015 & $3 \mathrm{fl}$. & - \\
\hline $\begin{array}{l}\text { Keprník, alpine grassland on both left and right edges } \\
\text { of the tourist path to the summit on the N slope of } \\
\text { the mountain, not. J. Kocián }\end{array}$ & $\begin{array}{l}50^{\circ} 10^{\prime} 25.5^{\prime \prime} \mathrm{N} \\
17^{\circ} 06^{\prime} 52.2^{\prime \prime} \mathrm{E}\end{array}$ & 1375 & 8. 7. 2015 & $15 \mathrm{fl}$. & - \\
\hline $\begin{array}{l}\text { Keprník, alpine grassland by the rocks } 130 \mathrm{~m} \mathrm{NW} \\
\text { of the Keprník summit, not. J. Kocián }\end{array}$ & $\begin{array}{l}50^{\circ} 10^{\prime} 18.2^{\prime \prime} \mathrm{N} \\
17^{\circ} 066^{\prime} 55.1^{\prime \prime} \mathrm{E}\end{array}$ & 1410 & 8. 7. 2015 & $7 \mathrm{fl}$. & - \\
\hline $\begin{array}{l}\text { Keprník, alpine grassland on the right edge of } \\
\text { the tourist path to the summit, } 15 \mathrm{~m} \mathrm{~N} \text { of } \\
\text { the summit path branching, not. J. Kocián }\end{array}$ & $\begin{array}{l}50^{\circ} 10^{\prime} 16.4^{\prime \prime} \mathrm{N} \\
17^{\circ} 07^{\prime} 00.8^{\prime \prime} \mathrm{E}\end{array}$ & 1415 & 8. 7. 2015 & $4 \mathrm{fl}$. & - \\
\hline $\begin{array}{l}\text { Červená hora, alpine grassland } 30 \mathrm{~m} \mathrm{NE} \\
\text { of the summit along the yellow path, leg. J. Kocián }\end{array}$ & $\begin{array}{l}50^{\circ} 08^{\prime} 46.9^{\prime \prime} \mathrm{N} \\
17^{\circ} 08^{\prime} 11.0^{\prime \prime} \mathrm{E}\end{array}$ & 1320 & 15. 7. 2008 & rare & NJM \\
\hline $\begin{array}{l}\text { V̌resová studánka, anthropogenic herb-rich slope } \\
50 \mathrm{~m} \text { NEE above the spring, not. J. Kocián }\end{array}$ & $\begin{array}{l}50^{\circ} 08^{\prime} 44.0^{\prime \prime} \mathrm{N} \\
17^{\circ} 08^{\prime} 05.4^{\prime \prime} \mathrm{E}\end{array}$ & 1290 & 7. 7. 2011 & $16 \mathrm{fl}$. & - \\
\hline $\begin{array}{l}\text { Červená hora, SE slope, drainage along the red } \\
\text { tourist path } 90 \mathrm{~m} \text { NW of Bílý sloup signpost, not. } \\
\text { J. Kocián }\end{array}$ & $\begin{array}{l}50^{\circ} 08^{\prime} 22.8^{\prime \prime} \mathrm{N} \\
17^{\circ} 08^{\prime} 23.1^{\prime \prime} \mathrm{E}\end{array}$ & 1225 & 7. 7. 2011 & $10 \mathrm{fl}$. & - \\
\hline $\begin{array}{l}\text { Tabulové skály, alpine grassland under the rocks, } \\
\text { not. J. Kocián }\end{array}$ & $\begin{array}{l}50^{\circ} 05^{\prime} 11.6^{\prime \prime} \mathrm{N} \\
17^{\circ} 13^{\prime} 49.9^{\prime \prime} \mathrm{E}\end{array}$ & 1450 & 2.7. 2016 & $2 \mathrm{fl}$. & - \\
\hline $\begin{array}{l}\text { Praděd, alpine grassland } 30 \mathrm{~m} \text { SE of border stone, } \\
\text { not. J. Kocián }\end{array}$ & $\begin{array}{l}50^{\circ} 05^{\prime} 04.6^{\prime \prime} \mathrm{N} \\
17^{\circ} 13^{\prime} 55.4^{\prime \prime} \mathrm{E} \\
\end{array}$ & 1480 & 12. 7. 2015 & $1 \mathrm{fl}$. & - \\
\hline $\begin{array}{l}\text { Praděd, summit, unused path descending southward } \\
\text { and anthropogenically influenced place nearby, not. } \\
\text { J. Kocián }\end{array}$ & $\begin{array}{l}50^{\circ} 04^{\prime} 56.4^{\prime \prime} \mathrm{N} \\
17^{\circ} 13^{\prime} 52.6^{\prime \prime} \mathrm{E}\end{array}$ & 1485 & 12. 7. 2015 & 5T fl. & - \\
\hline $\begin{array}{l}\text { Praděd, alpine grassland along the unused path on } \\
\text { SW slope of the mountain, not. J. Kocián }\end{array}$ & $\begin{array}{l}50^{\circ} 04^{\prime} 55.1^{\prime \prime} \mathrm{N} \\
17^{\circ} 13^{\prime} 40.7^{\prime \prime} \mathrm{E}\end{array}$ & 1470 & 12. 7. 2015 & $7 \mathrm{fl}$. & - \\
\hline $\begin{array}{l}\text { Praděd, alpine grassland along the unused path on } \\
\text { S slope of the mountain, not. J. Kocián }\end{array}$ & $\begin{array}{l}50^{\circ} 04^{\prime} 51.9^{\prime \prime} \mathrm{N} \\
17^{\circ} 13^{\prime} 52.1^{\prime \prime} \mathrm{E}\end{array}$ & 1450 & 26. 7. 2015 & 7T fl. & - \\
\hline $\begin{array}{l}\text { Vysoká hole, left grassy edge of the road to Praděd, } \\
400 \text { m NW of Ovčárna, not. J. Kocián }\end{array}$ & $\begin{array}{l}50^{\circ} 04^{\prime} 22.4^{\prime \prime} \mathrm{N} \\
17^{\circ} 14^{\prime} 01.2^{\prime \prime} \mathrm{E}\end{array}$ & 1315 & 6.7. 2011 & $18 \mathrm{fl}$. & - \\
\hline $\begin{array}{l}\text { Petrovy kameny, alpine grassland } 40 \mathrm{~m} \mathrm{NE} \text { of } \\
\text { the rock, not. J. Kocián }\end{array}$ & $\begin{array}{l}50^{\circ} 04^{\prime} 07.9^{\prime \prime} \mathrm{N} \\
17^{\circ} 14^{\prime} 02.7^{\prime \prime} \mathrm{E}\end{array}$ & 1425 & 10.7.2016 & $7 \mathrm{fl}$. & - \\
\hline $\begin{array}{l}\text { Vysoká hole, alpine grassland along the path to } \\
\text { Petrovy kameny branching from the red tourist path, } \\
150 \mathrm{~m} \text { SE of Petrovy kameny, not. J. Kocián }\end{array}$ & $\begin{array}{l}50^{\circ} 04^{\prime} 02.3^{\prime \prime} \mathrm{N} \\
17^{\circ} 14^{\prime} 05.6^{\prime \prime} \mathrm{E}\end{array}$ & 1425 & 12. 7. 2015 & $13 \mathrm{fl}$. & - \\
\hline $\begin{array}{l}\text { Vysoká hole, alpine grassland in an artillery hole, } \\
300 \mathrm{~m} \text { SEE of the field station, not. J. Kocián }\end{array}$ & $\begin{array}{l}50^{\circ} 03^{\prime} 29.4^{\prime \prime} \mathrm{N} \\
17^{\circ} 13^{\prime} 55.1^{\prime \prime} \mathrm{E}\end{array}$ & 1455 & 29. 8. 2015 & $25 \mathrm{fl}$. & - \\
\hline
\end{tabular}




\begin{tabular}{|l|l|l|l|l|l|}
\hline Locality & GPS & Alt. & Date & Count & Herb. \\
\hline $\begin{array}{l}\text { Velký máj, alpine grassland along the red tourist path, } \\
\text { leg. J. Kocián }\end{array}$ & $\begin{array}{l}50^{\circ} 02^{\prime} 41.2^{\prime \prime} \mathrm{N} \\
17^{\circ} 12^{\prime} 47.2^{\prime \prime} \mathrm{E}\end{array}$ & 1380 & 16.7 .2008 & rare & NJM \\
\hline
\end{tabular}
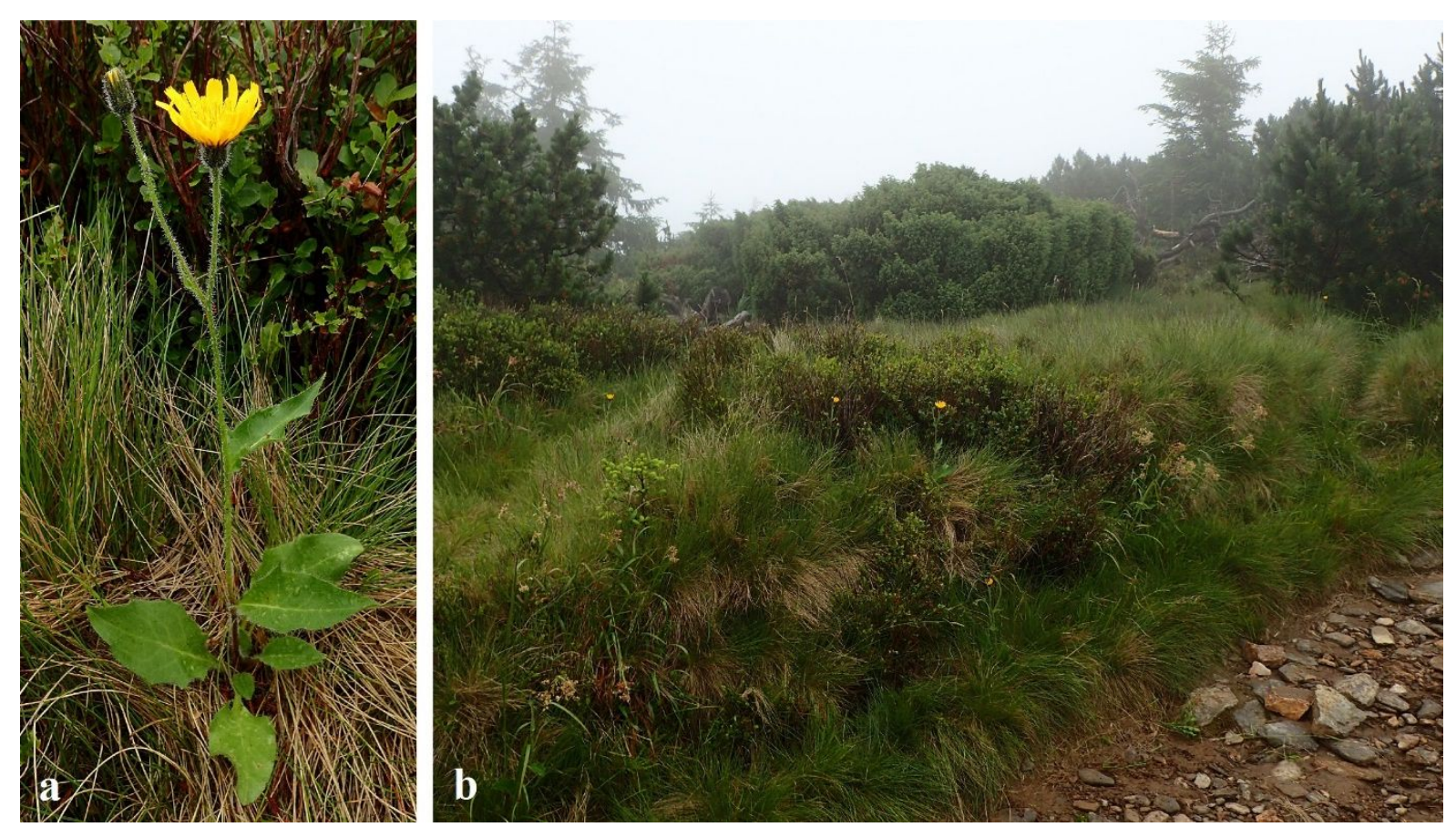

Fig 5: Hieracium nigritum: a - plant, b - locality along the tourist path to Keprník; the only surviving Keprník's Juniperus communis subsp. nana Syme on the background (both photos 8. VII. 2015). Photos Jiří Kocián.

Hieracium nigritum still grows in several localities scattered throughout the whole HJM main ridge, however, it is apparently less abundant than in the past.

The typical feature of this species is that there are often several flowering stems growing in clusters from one rhizome.

\section{Hieracium plumbeum Fries}

Complete general distribution of Hieracium plumbeum is not known. Its range in Fennoscandia and Eastern Europe comprises south and central parts of Norway and Sweden, Denmark, south part of Finland, north part of Latvia and northwest parts of Estonia and Russia (Sennikov 2005). In Central Europe there are only several localities reported from the HJM and the Carpathians (Zahn 1922-1938); the occurrence in the Harz Mts is also possible (Tyler \& Jonsson 2009). In the Czech Republic it grows only in the HJM (Zahn 1922-1938).

\section{Historical distribution in the HJM}

Herbarium specimens: Keprník: Bubela 1884 PR (P4S417/538); Müller 1887 BRNM (252335); Oborny 1900 BRNM (02677/31, 02678/31); Oborny 1900 BRNU (64302); Laus 1904 BRNU (44562); Missbach 1906 PR (P4S417/536); Oborny 1908 PR (P4S417/539); Hochshar. Köpernik: Laus 1905 BRNU (28503).

Literature data: Fiek 1881: An felsigen Orten des Hochgeb., sehr selten u. bisher nur sparsam am Köpernikstein im Gesenke (Wk!.). Oborny 1885: Felsige Orte im Hochgesenke, höchst selten, bisher nur am Köperniksteine (Winkler). Oborny 1906: Felsige Orte im Hochgesenke sehr selten und nur um die Köperniksteine zu finden. Skřivánek 1956: [not mentioned]. 

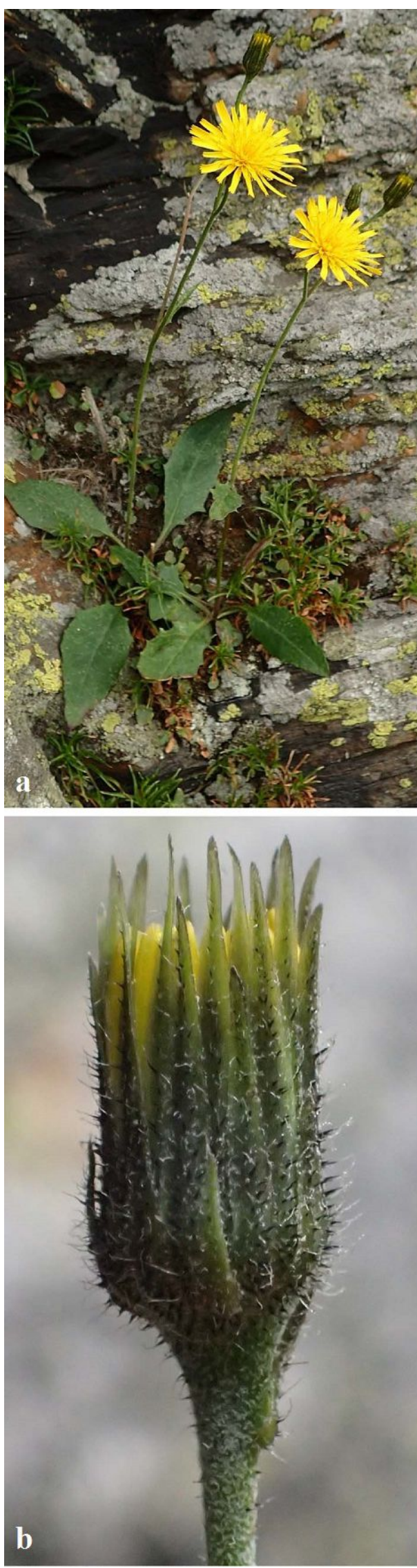
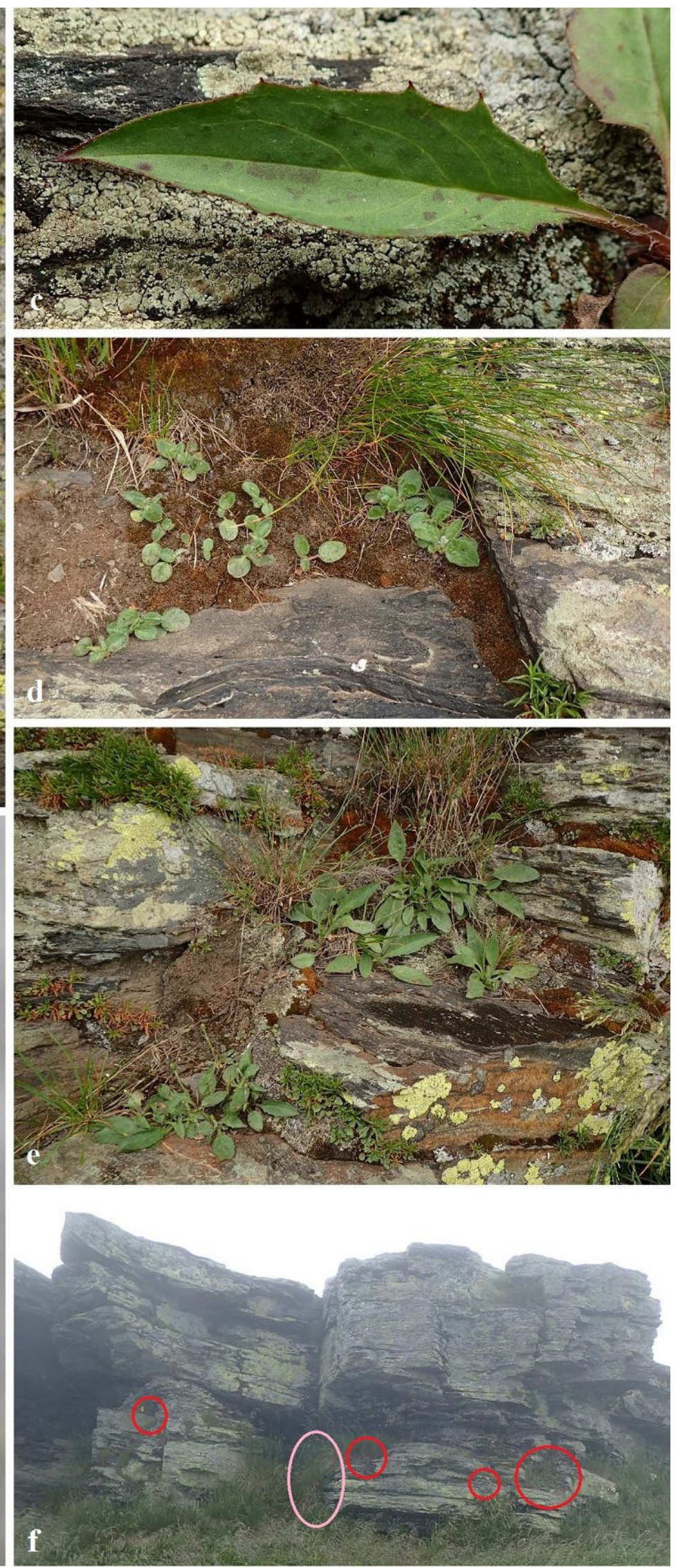

Fig 6: Hieracium plumbeum on Keprník (a-e): a - plants, b - involucre, c - basal leaf, d and e - subpopulations. Keprník summit rock (f): plants and subpopulations of Hieracium plumbeum in red circles, population of Hieracium atratum agg. in pink elipse (all photos 8. VII. 2015). Photos Petr Kocián. 
The only traditional and reliably documented locality of Hieracium plumbeum in the HJM is Keprník. The species was last documented from there at the beginning of the 20th century. No one has confirmed the species' occurrence in the HJM since that time.

\section{Current distribution in the HJM}

Table 11: Current localities of Hieracium plumbeum in the HJM

\begin{tabular}{|l|l|l|l|l|l|}
\hline Locality & GPS & Alt. & Date & Count & Herb. \\
\hline $\begin{array}{l}\text { Keprník, crevices on the E part of the summit rock, } \\
\text { leg. J. Kocián }\end{array}$ & $\begin{array}{l}50^{\circ} 10^{\prime} 15.4^{\prime \prime N} \\
17^{\circ} 06^{\prime} 59.5^{\prime \prime}\end{array}$ & 1423 & 11.9 .2012 & $\begin{array}{l}18 \mathrm{fl} . \\
(2015)\end{array}$ & BRNU \\
\hline $\begin{array}{l}\text { Königskoppe, dry scree under one of the rocks } \\
\text { above the forest road on S slope, leg. L. Bureš }\end{array}$ & $\begin{array}{l}50^{\circ} 06^{\prime} 06.2^{\prime \prime N} \\
17^{\circ} 14^{\prime} 20.6^{\prime \prime} \mathrm{E}\end{array}$ & 1065 & 11.8 .2009 & $8 \mathrm{fl}$. & SUM \\
\hline $\begin{array}{l}\text { Praděd, grassy slope on the right edge of the road to } \\
\text { Praděd ca 50 m SW of touristic signpost "Pod } \\
\text { Pradědem“, leg. J. Kocián }\end{array}$ & $\begin{array}{l}50^{\circ} 05^{\prime} 00.3^{\prime \prime N}, \\
17^{\circ} 13^{\prime} 17.9^{\prime \prime} \mathrm{E}\end{array}$ & 1420 & 9.7 .2006 & $20 \mathrm{fl.}$ & $\begin{array}{l}\text { NJM, } \\
\text { BRNU }\end{array}$ \\
\hline
\end{tabular}

Besides rediscovering Hieracium plumbeum on Keprník we also newly discovered it in two localities: Königskoppe and Praděd. The populations are small but seem to be stable in time. The traditional population on Keprník is occasionally damaged by tourists sitting on the rock where the plants grow.

Although we determined the plants found on Praděd in 2006 as Hieracium bifidum agg., we started to doubt this determination later. Thus, we decided to send the plants to Alexander Sennikov, an expert on this hawkweed group. He confirmed our suggestion and determined plants as Hieracium plumbeum. HJM plants differ slightly from the typical Fennoscandinavian ones in the leaf base shape. Nevertheless, all other features (branching pattern of inflorescence, size and shape of heads, shape and pubescence of phyllaries, size and colour of hairs, colour and pubescence of leaves) match with the features of the Fennoscandinavian plants (A. Sennikov in litt. 2013). Thus, based on morphology, HJM plants are classifiable as H. plumbeum. However, it is strange for an apomictic species to occupy such a large area. A genetic study would be required to elucidate the exact relationship of HJM plants and the Fennoscandinavian ones.

\section{Hieracium prenanthoides agg.}

Hieracium prenanthoides is a highly polymorphic, polyploid and taxonomically difficult aggregate species. It has a vast but disjunctional range encompassing particularly European, Western and Central Asian mountain ranges, descending to lower altitudes in the north part of its range (Zahn 1922-1938). Its occurrence in the Czech Republic is known from the Krkonoše Mts, Mt. Králický Sněžník and the HJM (Zahn 1.c.).

\section{Historical distribution in the HJM}

Herbarium specimens: Hieracium prenanthoides agg. is taxonomically unresolved aggregate species and therefore only the overview of herbarium localities is given: Keprník, Vozka, Vřesová studánka, Malý Děd, Praděd, Barborka, Mravenečník, Divoká Desná valley, Petrovy kameny, Vysoká hole, Velká kotlina, Františkova myslivna, Alfrédova myslivna.

Literature data: Fiek 1881: (ut H. prenanthoides Vill. a) bupleurifolium W. Gr.:) Leiterberg im Gesenke (Gr.)! (ut H. prenanthoides Vill. $\beta$ perfoliatum Froel.:) im Gesenke im Kessel (M. Wkl.)! (ut H. prenanthoides Vill. b) angustifolium Tausch:) So besonders [...] im Gesenke. Oborny 1885: (ut H. prenanthoides Vill. a) bupleurifolium W. Gr.:) In den niederen Lagen des Hochgesenkes, namentlich an den Wasserläufen oft bis zu den Dörfern, etwa zu $850^{\mathrm{m}}$. herabreichend, so um Annaberg an der Thess, am Fusse des Leiterberges bei Winkelsdorf, knapp oberhalb der Försterei Hubertuskirchen bei Karlsbrunn (N.) etc; häufiger im Gebiete bis zur oberen Waldregion: Leiterberg, 
Brünnelheide, Wiegenstein, Bärenkamm, Ameisenhügel, Franzensjagdhaus; eine forma lanceolata [...] in der Waldregion des Altvaters und im Thessgraben bei Annaberg und eine deutlich gezähnte Form [...] am Leiterberge. (ut $H$. prenanthoides * ramigerum Fr.:) am Leiterberge (Gr.). (ut $H$. prenanthoides Vill. $\beta$ perfoliatum Fröhl.:) Sehr selten: Gr. Kessel im Gesenke (Winkler), eine ähnliche Form auf dem Ameisenhügel bei Wiesenberg. (ut $H$. prenanthoides Vill. b) angustifolium Tausch:) im mähr. Gesenke häufig, namentlich in den Höhen nahe um die Grenze des Waldwuchses und über diese Grenze fast auf allen Höhen: Köpernik, Hochschar, Fuhrmannstein, Brünnelheide, Leiterberg, Altvater, Hohe Heide gr. und kl. Kessel, Hirschbrunnen, Ameisenhügel, Franzensjagdhaus und sonst fast überall auf diesem Gebirgskamme. Oborny 1906: (ut H. prenanthoides Vill. ssp. bupleurifolium Tsch.:) Beide Formen im Verlaufe des Gesenkes nicht selten und oft denselben Standort theilend. Der Typus häufiger u. z.: Leiterberg (Grabowsky), [...] Köpernik, Gr.-Seeberg (Fm.), Brünnelheide, Bärenkamm, Ameisenhügel, Franzensjagdhaus, Altvater, Neudorfer Kessel, grosser Kessel, Hubertuskirchen bei Karlsbrunn u. a. O. $\beta$ seltener: Grosser Kessel (Winkler), Thessgraben bei Annaberg, Neudorfer Kessel, Franzens-Jagdhaus. (ut H. prenanthoides ssp. lanceolatum Vill.:) im Verlaufe des ganzen Gesenkes ziemlich häufig, so auf den Abhängen des Köpernik, der Hochschar, Abhänge der Fuhrmannsteine, der Brünnelheide, am Leiterbrge, Altvater, beim Jagdhause, im grossen und kleinen Kessel, auf der hohen Heide, Petersteine, am Hirschkamm, Ameisenhügel u. a. O. (ut H. prenanthoides Vill. var. $\beta$ strictissimum Froel.:) im grossen Kessel, bei der Schäferei, am Horizontalwege zwischen dem Franzens-Jagdhause und den Petersteinen. Skřivánek 1956: Hieracium prenanthoides Vill. horské nivy, občas na prameništích a podél horních toků říček, ssp. bupleurifolium (Tausch) Zahn - Velký Kotel 28. 6. 1946 a 4. 8. 1953, Malý Kotel 8. 8. 1955. Hieracium lanceolatum Vill. - na podobných místech jako předchozí [H. prenanthoides], ale daleko hojnější. Řadím sem typy označené jako $H$. angustifolium Tausch. Jižní svahy Pradědu a kolem Barborky 4. 8. 1946, Velký Kotel, Vysoká Hole 4. 8. 1953, svahy mezi Velkým a Malým Kotlem 9. 8. 1955.

\section{Current distribution in the HJM}

We ascertained three contemporary localities of Hieracium prenanthoides agg. The centre of distribution is located in Velká kotlina where it grows at about 35 sites (ca 750 flowering plants in total; the sites are displayed on Map 1). Rich populations (ca 175 flowering plants in total) are to be found on anthropogenically influenced slopes above the Ovčárna chalet and around the mountain rescue service lodge. The third locality is in Malá kotlina - we recorded seven flowering plants in 2012, only 2 dried plants in 2013 and no plants in 2016 on a small rock in the upper south part of glacial cirque at $1225 \mathrm{~m}$ a.s.1., GPS: $50^{\circ} 02^{\prime} 20.7^{\prime \prime} \mathrm{N}, 17^{\circ} 12^{\prime} 34.3^{\prime \prime} \mathrm{E}$ (all localities leg. or not. by J. Kocián). We did not find the species on Vřesová studánka, Malý Děd, Praděd and Barborka in spite of intensive endeavour to find it on these localities since 2008.

Hieracium prenanthoides agg. comprises several microspecies in the HJM. The aggregate's complicated taxonomy and variability in Central Europe (i.e. including the HJM) is a subject of ongoing long term research undertaken by the first author of this article. Because of many yet unresolved questions in this hawkweed group the localities given both in the text and in the map showing the distribution in Velká kotlina (Fig 1) are related to the whole aggregate, not distinguishing microspecies.

\section{Hieracium silesiacum E. Krause}

Hieracium silesiacum is HJM subendemic species. Apart from the HJM (Zahn 1922-1938) it grows very rarely in the Western Carpathians in the Západní Tatry Mts and west part of the Vysoké Tatry Mts (Chrtek et al. 2002, Mráz 2005). Formerly noted occurrence in the Nízké Tatry Mts was refuted by Ronikier \& Szeląg (2008) - the plants from this area belong to another species. Hieracium silesiacum is the only Sudeten species of Hieracium sect. Cernua Uechtr.; the section has a centre of distribution on the Balkan Peninsula and in the South Carpathians (Szeląg 2003). 


\section{Historical distribution in the HJM}

Herbarium specimens: Praděd: Šourek, Skřivánek 1946 PR (275931); Barborka: Skřivánek 1953 OP (24754); Deyl 1965 OLM (147156); Vysoká hole: Laus 1927 OLM (69711); Laus 1930 BRNU (217311, 399659); Laus 1935 PR (P4S417/5737); Laus 1938 OLM (69708, 69709, 69710); Velká kotlina: Oborny 1877 BRNU (62616); Freyn 1878 PR (P4S417/3071); Freyn 1883 PRC (22252/36); Freyn 1883 PR (P4S417/3067); Bubela 1884 BRNU (195455); Bubela 1884 PR (P4S417/9417); Spitzner 1886 BRNU (135456); Oborny 1887 PR (P4S417/3069); Schierl 1890 PR (275933); Missbach 1906 BRNU (159382); Missbach 1906 PR (P4S417/3070); Laus 1908 BRNU (28022, 413012); Laus 1908 PR (P4S417/5944); Oborny 1908 PR (P4S417/3072); Laus 1909 BRNU (28023); Laus 1909 PR (P4S417/3068); Laus 1911 BRNU (28021); Laus 1911 OLM (69714); Laus 1929 BRNU (378347); Otruba 1931 OLM (69715); Prinz 1931 PR (P4S417/7047); Laus 1932 OLM (69712, 69713); Laus 1932 OP (164497); Otruba 1932 PR (P4S417/9205); Laus 1933 OP (20338); Otruba 1933 OLM (69716); Skřivánek 1946 BRNU (360961); Skřivánek 1946 MP (28933); Šourek 1946 PR (275932); Dostál, Bednár 1965 PR (P4S417/9037); Janáčková 1971 SUM (6801, 6837); Deyl 1975 OLM (147155).

Note: Szeląg (2004) presents many other herbarium specimen of Hieracium silesiacum in BRNM and WRSL from several HJM localities: Praděd: Callier, Hirte, Scholz 1893 WRSL (s.n.); Teuber 1925 BRNM (66577); Kleiner Vaterberg: Oborny 1900 BRNM (22248/36); Pramen Opavice: Skřivánek 1946 BRNM (19270); Opavice: Skřivánek 1946 BRNM (255192, 255185); Vysoká hole: Freyn 1883 BRNM (22253/36); Skřivánek 1953 BRNM (255193); Velká kotlina: Winkler 1849 BRNM (22251/36); Fiek 1874 WRSL (s.n., s.n.); Oborny 1876 BRNM (22244/36); Freyn 1878 BRNM (22256/36, 22255/36, 22254/36); Fritze 1878 BRNM (22250/36); Winkler 1879 WRSL (s.n.); Oborny 1882 WRSL (s.n.); Bubela 1884 WRSL (s.n.); Formánek 1884 BRNM (22240/36, 22241/36, 22242/36); Fritze 1888 WRSL (s.n.); Müller 1889 BRNM (255186); Oborny 1900 BRNM (22247/36); Oborny 1903 BRNM (22246/36); Laus 1908 BRNM (22243/36); Laus 1908 BRNU (28022, 413012); Otruba 1937 BRNM (255190); Skřivánek 1946 BRNM (255139, 399658, 255187, 255191); Zavřel 1950 BRNM (255183, 255195); Skřivánek 1953 BRNM (255194); Černoch 1962 BRNM (516951); Fiek s.d. WRSL (s.n.); Freyn, Oborny s.d. BRNM (22249/36); s. coll. s.d. BRNM (22245/36). We were not able to find these specimens in the herbaria.

Literature data: Fiek 1881: Wiesen u. grasige Lehnen der östl. Hochsudeten, selten. Im Gesenke an der Hungerlehne (Kr.), Leiterberg vereinzelt, zahlreich am Abhange des Altvater beim Oppafalle (Oborny), oberer Rand des Kessels! (hier 1846 von Kr. entd.), Ameisenhügel am Wege von Franzens Jagdhause zur Lehmbaude bei Wiesenberg spärlich, 1300 m. (Oborny). Oborny 1885: Wiesen und kräuterreiche Grasplätze, nur im mähr. Gesenke, selten. Oberer Rand des gr. Kessels (Krause, 1846 entdeckt.); Hungerlehne (Kr); vereinzelt auf dem Leiterberge, Abhang gegen Thomasdorf (1879), häufiger auf dem Altvater, Abdachung gegen die Oppa-Quellen; seltened auf dem Ameisenhügel, am Wege vom Jagdhause zur Lehmbaude bei Wiesenberg, etwa bei $1300 \mathrm{~m}$ Seehöhe. Oborny 1906: Kräuterreiche Grasplätze im Mähr. Gesenke: Gr. Kessel (hier 1846 von Krause entdeckt), Abhang den hohen Heide gegen Karlsdorf, Altvater, Abhang gegen die Oppaquellen, Ameisenhügel, Hungerlehne, Leiterberg, hier sehr selten. Skřrivánek 1956: horské nivy, nehojně, horní okraj Velkého kotle, prameny Opavice a svahy Pradědu k Barborce 4. 8. 1946, Vysoká hole 4. 8. 1953. -- V roce 1946 zjistil jsem u pramene Opavice pod chatou Barborkou bohaté naleziště vzácného druhu H. silesiacum. Jmenované naleziště, jak jsem se v roce 1955 přesvědčil, bylo důsledkem terénních úprav koryta Opavice a úpravy prostoru kolem chaty Barborky zničeno a na místě nyní vegetuje $H$. vulgatum.

Hieracium silesiacum was discovered on Hungerlehne and in Velká kotlina in 1846 by E. Krause who later described it from the latter locality (Krause 1851). Although about eight localities were reported from the HJM, the considerable majority of herbarium specimens are located from Velká kotlina (see Fig 9). The occurrence on Praděd, near Bílá Opava and on Vysoká hole is documented by only a few herbarium specimens and there is only one from Kleiner Vaterberg. No herbarium specimens for other localities are available. This significantly reflects historical species' abundance on particular localities. The centre of distribution and the richest locality is clearly Velká kotlina. Then the only relatively rich occurrences are documented and as that also mentioned in literature (Fiek 1881, Oborny 1885) from Praděd or Bílá Opava springs / near Bílá Opava current and from Vysoká hole. The occurrence was rare on the rest of the localities. Sole findings on Hungerlehne (Krause's finding first mentioned in Krause 1851) and Mravenečník (Oborny's finding first mentioned in Fiek 1881) were only adopted by later authors. The occurrence on Šerák is mentioned only by Hruby (1914). 
Current distribution in the HJM

Table 12: Current localities of Hieracium silesiacum in the HJM

\begin{tabular}{|c|c|c|c|c|c|}
\hline Locality & GPS & Alt. & Date & Count & Herb. \\
\hline $\begin{array}{l}\text { Praděd, S slope, grassy vegetation } 80 \mathrm{~m} \mathrm{~W} \text { of } \\
\text { Barborka chalet, not. J. Kocián }\end{array}$ & $\begin{array}{l}50^{\circ} 04^{\prime} 36.7^{\prime \prime} \mathrm{N} \\
17^{\circ} 13^{\prime} 47.8^{\prime \prime} \mathrm{E}\end{array}$ & 1325 & 1. 8. 2012 & $14 \mathrm{fl}$. & - \\
\hline $\begin{array}{l}\text { Praděd, S slope, grassy vegetation } 50 \mathrm{~m} \mathrm{~W} \text { of } \\
\text { Barborka chalet above the place with benches, leg. } \\
\text { J. Kocián }\end{array}$ & $\begin{array}{l}50^{\circ} 04^{\prime} 36.4^{\prime \prime} \mathrm{N} \\
17^{\circ} 13^{\prime} 49.1^{\prime \prime} \mathrm{E}\end{array}$ & 1325 & 1. 8. 2012 & $30 \mathrm{fl}$. & BRNU \\
\hline $\begin{array}{l}\text { Velká kotlina, Kunzova stráň, subalpine tall } \\
\text { grassland, not. L. Bureš }\end{array}$ & $\begin{array}{l}50^{\circ} 03^{\prime} 33.2^{\prime \prime} \mathrm{N} \\
17^{\circ} 14^{\prime} 07.6^{\prime \prime} \mathrm{E}\end{array}$ & 1430 & 27.7 .2012 & $5 \mathrm{fl}$. & - \\
\hline $\begin{array}{l}\text { Velká kotlina, Kunzova stráň, subalpine tall } \\
\text { grassland around a small rock, three microsites, not. } \\
\text { J. Kocián }\end{array}$ & $\begin{array}{l}50^{\circ} 03^{\prime} 29.6^{\prime \prime} \mathrm{N} \\
17^{\circ} 14^{\prime} 10.7^{\prime \prime} \mathrm{E}\end{array}$ & 1360 & 10.7 .2016 & $5 \mathrm{fl}$. & - \\
\hline $\begin{array}{l}\text { Velká kotlina, sparse vegetation on elevated rocky } \\
\text { place between two rivulet streambeds in the upper } \\
\text { part of Velká kotlina, } 40 \mathrm{~m} \text { NE of Kettnerova skála; } \\
\text { another } 3 \text { flowering individuals ca } 10 \mathrm{~m} \text { NE of this } \\
\text { population, leg. J. Kocián }\end{array}$ & $\begin{array}{l}50^{\circ} 03^{\prime} 26.6^{\prime \prime} \mathrm{N} \\
17^{\circ} 14^{\prime} 10.0^{\prime \prime} \mathrm{E}\end{array}$ & 1330 & 22.7 .2012 & $35 \mathrm{fl}$. & BRNU \\
\hline $\begin{array}{l}\text { Velká kotlina, under N edge of Kettnerova skála, } \\
\text { outcrop, blueberry vegetation, not. J. Kocián }\end{array}$ & $\begin{array}{l}50^{\circ} 03^{\prime} 25.5^{\prime \prime} \mathrm{N} \\
17^{\circ} 14^{\prime} 09.1^{\prime \prime} \mathrm{E}\end{array}$ & 1330 & 22.7 .2012 & $2 \mathrm{fl}$. & - \\
\hline $\begin{array}{l}\text { Velká kotlina, subalpine grassland SW Vitáskova } \\
\text { rokle, above the continuation of path across the } \\
\text { ravine, several scattered clusters of few individuals } \\
\text { and sole plants, not. J. Kocián }\end{array}$ & $\begin{array}{l}\text { around } \\
50^{\circ} 03^{\prime} 21.7^{\prime \prime} \mathrm{N} \\
17^{\circ} 14^{\prime} 07.2^{\prime \prime} \mathrm{E}\end{array}$ & 1330 & 22.7 .2012 & $20 \mathrm{fl}$. & - \\
\hline $\begin{array}{l}\text { Velká kotlina, Fiekovy ohlazy, smooth rock with } \\
\text { dwarf bush vegetation, not. J. Kocián }\end{array}$ & $\begin{array}{l}50^{\circ} 03^{\prime} 21.1^{\prime \prime} \mathrm{N} \\
17^{\circ} 14^{\prime} 08.7^{\prime \prime} \mathrm{E}\end{array}$ & 1295 & 10.7 .2016 & $6 \mathrm{fl}$. & - \\
\hline $\begin{array}{l}\text { Velká kotlina, Fiekovy ohlazy, smooth rock with } \\
\text { sparse vegetation, not. J. Kocián }\end{array}$ & $\begin{array}{l}50^{\circ} 03^{\prime} 20.8^{\prime \prime} \mathrm{N} \\
17^{\circ} 14^{\prime} 07.8^{\prime \prime} \mathrm{E}\end{array}$ & 1305 & 20.7 .2013 & $10 \mathrm{fl}$. & - \\
\hline $\begin{array}{l}\text { Velká kotlina, Fiekovy ohlazy, grassy vegetation on } \\
\text { the small rocks, not. J. Kocián }\end{array}$ & $\begin{array}{l}50^{\circ} 03^{\prime} 20.6^{\prime \prime} \mathrm{N} \\
17^{\circ} 14^{\prime} 08.7^{\prime \prime} \mathrm{E}\end{array}$ & 1290 & 10. 7. 2016 & $14 \mathrm{fl}$. & - \\
\hline $\begin{array}{l}\text { Velká kotlina, Fiekovy ohlazy, grassy edge of small } \\
\text { outcrop, not. J. Kocián }\end{array}$ & $\begin{array}{l}50^{\circ} 03^{\prime} 20.2^{\prime \prime} \mathrm{N} \\
17^{\circ} 14^{\prime} 05.1^{\prime \prime} \mathrm{E}\end{array}$ & 1335 & 5.8.2012 & $20 \mathrm{fl}$. & - \\
\hline $\begin{array}{l}\text { Velká kotlina, S edge of Fiekovy ohlazy, subalpine } \\
\text { tall grassland, not. J. Kocián }\end{array}$ & $\begin{array}{l}50^{\circ} 03^{\prime} 16.8^{\prime \prime} \mathrm{N} \\
17^{\circ} 14^{\prime} 03.5^{\prime \prime} \mathrm{E}\end{array}$ & 1335 & 5. 8. 2012 & $2 \mathrm{fl}$. & - \\
\hline $\begin{array}{l}\text { Velká kotlina, Molinia grassland under Suzova stěna, } \\
\text { not. J. Kocián }\end{array}$ & $\begin{array}{l}50^{\circ} 03^{\prime} 16.6^{\prime \prime} \mathrm{N} \\
17^{\circ} 14^{\prime} 11.8^{\prime \prime} \mathrm{E}\end{array}$ & 1205 & 18.7 .2015 & $1 \mathrm{fl}$. & - \\
\hline $\begin{array}{l}\text { Velká kotlina, Fiekovy ohlazy, small grassy rock, } \\
\text { two microsites, not. J. Kocián }\end{array}$ & $\begin{array}{l}50^{\circ} 03^{\prime} 16.3^{\prime \prime} \mathrm{N} \\
17^{\circ} 14^{\prime} 05.1^{\prime \prime} \mathrm{E}\end{array}$ & 1310 & 23.7 .2016 & $6 \mathrm{fl}$. & - \\
\hline $\begin{array}{l}\text { Velká kotlina, S edge of Fiekovy ohlazy, dense } \\
\text { subalpine tall grassland, not. J. Kocián }\end{array}$ & $\begin{array}{l}50^{\circ} 03^{\prime} 15.7^{\prime \prime} \mathrm{N} \\
17^{\circ} 14^{\prime} 04.8^{\prime \prime} \mathrm{E}\end{array}$ & 1310 & 20.7. 2013 & $1 \mathrm{fl}$. & - \\
\hline $\begin{array}{l}\text { Velká kotlina, Mildeho skalka, steep slope with } \\
\text { subalpine tall grassland, not. J. Kocián }\end{array}$ & $\begin{array}{l}50^{\circ} 03^{\prime} 15.2^{\prime \prime} \mathrm{N} \\
17^{\circ} 14^{\prime} 06.4^{\prime \prime} \mathrm{E}\end{array}$ & 1285 & 20.7 .2013 & $5 \mathrm{fl}$. & - \\
\hline
\end{tabular}

We confirmed current occurrence of Hieracium silesiacum at two localities: in Velká kotlina and on the south slope of Praděd near Barborka chalet. In Velká kotlina the species grows, in confirmity with literary data, mostly in its upper part. We found three numerous populations and eleven smaller ones. Two populations near Barborka chalet grow on the place which was heavily anthropogenically influenced in the past but which has semi-natural character contemporarily. 
We were not successful in confirming Hieracium silesiacum at other historical localities (Vysoká hole, Mravenečník, Malý Děd, Hungerlehne, Šerák). The species might have been neglected but considering its rare occurrence in these localities in the past and vegetation changes in subalpine zone of the HJM during the last decades it is most likely to be extinct there now.

\section{Hieracium stygium R. Uechtr.}

Hieracium stygium grows in the East Sudeten Mts and the Western Carpathians (Zahn 1922-1938). In the Czech Republic it grows on Mt. Králický Sněžník, in the Rychleby Mts and in the HJM (Zahn 1. c.).

\section{Historical distribution in the HJM}

Herbarium specimens: Herbarium specimens of Hieracium stygium are the second most numerous among all HJM hawkweed species and they are present in all studied herbaria. Their locations cover the whole main HJM ridge.

Oborny (1906) and Skřivánek (1956) report Hieracium stygium as the most abundant HJM hawkweed together with Hieracium vulgatum. Also Chrtek (2004) denotes it as the most abundant hawkweed in the subalpine zone of the HJM despite the species' decline during the second half of the 20th century.

\section{Current distribution in the HJM}

Contemporarily, Hieracium stygium is still the most abundant HJM hawkweed. It grows scattered in the whole subalpine and less often in the supramontane zone of the HJM. Its estimated population size is a few thousand plants. The prevailing sites are the edges of tourist paths. It is remarkable that it grows only rarely in Velká kotlina. It is also rather rare on the alpine grasslands of the south part of Pradědská hornatina (from Vysoká hole to Pec).

\section{Hieracium villosum Jacq.}

Hieracium villosum grows in the mountains of Central and Southern Europe (Zahn 19221938). In the Czech Republic it grows only in the HJM (Zahn 1.c.).

\section{Historical distribution in the HJM}

Herbarium specimens: Petrovy kameny: Formánek 1884 BRNM (02430/31); Velká kotlina: Zimmermann 1875 WRSL (s.n.); Oborny 1876 PRC (s.n.); Oborny 1877 BRNM (02436/31); Freyn 1878 BRNM (02433/31); Winkler 1879 BRNM (02434/31); Winkler 1879 WRSL (s.n.); Freyn 1883 BRNM (02435/31); Ficinus 1883 WRSL (s.n.); Rieger 1890 OP (96710); Fiek 1895 WRSL (s.n.); Teuber 1902 BRNM (18800); Schustler 1919 PR (P4S417/10543); Laus 1930 OLM (69803); Laus 1930 OP (20352); Otruba 1930 OLM (69805, 69806, 69808); Skřivánek 1946 BRNM (254592, 254595); Šmarda 1946 PR (P4S417/11054); David 1947 OP (88417); Deyl 1947 PR (P4S417/7392); Dostál 1947 PRC (s.n.); Deyl 1949 PR (P4S417/7412); Deyl 1952 PR (P4S417/5124, P4S417/5141); Šmarda 1954 BRNM (69836); Skřivánek 1955 BRNM (254594); Skřivánek 1956 BRNM (254593); Měsíček 1961 PR (P4S417/7284); Deyl 1966 PR (260080); Burešovi, Jeník 1972 OLM (109674); Severa 2000 PRC (s.n.); Grabowski s.d. BRNM (02432/31); Formánek s.d. BRNM (02431/31); Spatzier s. d. OP (12516); s. coll. s. d. OP (98188); s.coll. s.d. PR (P4S417/10071).

Note: Severa (2001) presents other herbarium specimens of Hieracium villosum from Velká kotlina in PRC but we were not able to find them in the herbarium.

Literature data: Fiek 1881: An Felsen in den östl. Hochsudeten, sehr selten. Im grossen Kessel des Gesenkes! (1834 von Gr. entd.). Oborny 1885: Felsspalten, steile Felshänge, sehr selten, bisher nur im grossen Kessel des Gesenkes, westliche Abdachung der Janowitzer Haide, 1834 v. Grabowsky entdeckt. Oborny 1906: im grossen Kessel des Gesenkes auf Felswänden bei $1440 \mathrm{~m}$ u. z. nur am Westrande des unteren Kessels. Skřivánek 1956: skály na západním okraji Velkého Kotle, pořídku, společně s Agrostis alpina, Hedysarum obscurum, Aster alpinus, Arabis sudetica, Helianthemum grandiflorum, cca 1200 m, 28. 6. 1946, 9. 8. 1955. 
The distribution of Hieracium villosum in the HJM is very well known thanks to the species' attractivity. The traditional locality is Velká kotlina where it was first found by E. H. Grabowski as early as in 1834 (Wimmer 1840). All herbarium specimens but one (Formánek's one from Petrovy kameny - this localization is, however, for many reasons almost certainly wrong) come from this locality. Velká kotlina is also the only locality of Hieracium villosum mentioned in the older literature. Another two HJM localities - Sokol and Volárna - were discovered only at the end of the 20th century. Sokol is listed by Chrtek (2004) for the first time but it is unknown who discovered this locality and when. The locality of Volárna near Mezikotlí was discovered by L. Bureš in 1989 (Bureš 2013). The plants grew on the wall of the former ox stable. Bureš (1.c.) also reports a locality along the path in the summit area of Kamzičník, however, this locality is wrong - plants of Hieracium alpinum were misidentified as $H$. villosum (cf. herbarium specimen in OLM, no. 109675). Hieracium villosum was discovered at another three new localities as late as the new millennium. M. Kočí found it on the ruins of a former sheep house located ca $900 \mathrm{~m}$ E of Barborka chalet on the south slope of Praděd and he mentions one flowering cluster on Tabulové skály found by V. Kavalcová (Kočí 2005). J. Chlapek found Hieracium villosum on Žárový vrch in 2006 (Bureš 2013). R. Štencl performed a field revision of all known localities in 2007 and 2008 (Štencl 2009). In conclusion, eight localities of Hieracium villosum were reported from the HJM, five of them are trustworthy (Velká kotlina, Sokol, Volárna, Praděd - ruins of a former sheep house, Žárový vrch), one is slightly doubtful (Tabulové skály), one is almost certainly wrong (Petrovy kameny) and one is wrong (Kamzičník).

\section{Current distribution in the HJM}

Table 13: Current localities of Hieracium villosum in the HJM

\begin{tabular}{|c|c|c|c|c|c|}
\hline Locality & GPS & Alt. & Date & Count & Herb. \\
\hline $\begin{array}{l}\text { Žárový vrch, summit rock, leg. J. Kocián } \\
\text { (independently by J. Chlapek in 2006) }\end{array}$ & $\begin{array}{l}50^{\circ} 06^{\prime} 31.4^{\prime \prime} \mathrm{N} \\
17^{\circ} 18^{\prime} 38.5^{\prime \prime} \mathrm{E}\end{array}$ & 1094 & 14.9. 2007 & $\begin{array}{l}17 \mathrm{fl} . \\
(2008)\end{array}$ & NJM \\
\hline $\begin{array}{l}\text { Žárový vrch, flat rock } 25 \mathrm{~m} \text { SE of the summit rock, } \\
\text { leg. J. Kocián (independently by J. Chlapek in 2006) }\end{array}$ & $\begin{array}{l}50^{\circ} 06^{\prime} 30.9^{\prime \prime} \mathrm{N} \\
17^{\circ} 18^{\prime} 39.9^{\prime \prime} \mathrm{E}\end{array}$ & 1090 & 14.9. 2007 & $\begin{array}{l}16 \mathrm{fl} . \\
(2008)\end{array}$ & NJM \\
\hline $\begin{array}{l}\text { Sokol, Sokolí skála, S summit area of the main rock, } \\
\text { leg. J. Kocián }\end{array}$ & $\begin{array}{l}50^{\circ} 05^{\prime} 39.8^{\prime \prime} \mathrm{N} \\
17^{\circ} 15^{\prime} 01.1^{\prime \prime} \mathrm{E}\end{array}$ & 1170 & 10.7 .2007 & $16 \mathrm{fl}$. & NJM \\
\hline $\begin{array}{l}\text { Praděd, S slope, stony ruin of former chalet, } 350 \mathrm{~m} \\
\text { SSE of altitudinal point } 1356 \text { and } 900 \mathrm{~m} \text { E of } \\
\text { Barborka chalet, not. J. Kocián }\end{array}$ & $\begin{array}{l}50^{\circ} 04^{\prime} 42.1^{\prime \prime N} \\
17^{\circ} 14^{\prime} 38.5^{\prime \prime} \mathrm{E}\end{array}$ & 1280 & 19.8 .2014 & $2 \mathrm{fl}$. & - \\
\hline $\begin{array}{l}\text { Velká kotlina, upper part of Vitáskova rokle, rock } \\
\text { above the path crossing the ravine, sole individuals } \\
\text { also on the rock left of Šmardova stěna, not. J. Kocián }\end{array}$ & $\begin{array}{l}50^{\circ} 03^{\prime} 22.6^{\prime \prime} \mathrm{N} \\
17^{\circ} 14^{\prime} 08.5^{\prime \prime} \mathrm{E}\end{array}$ & 1320 & 13.8 .2011 & $6 \mathrm{~T} \mathrm{fl}$. & - \\
\hline $\begin{array}{l}\text { Velká kotlina, Vitáskova rokle, } \mathrm{N} \text { wall of first pillar } \\
\text { of the ravine, not. L. Bureš }\end{array}$ & $\begin{array}{l}50^{\circ} 03^{\prime} 20.7^{\prime \prime} \mathrm{N} \\
17^{\circ} 14^{\prime} 10.9^{\prime \prime} \mathrm{E}\end{array}$ & 1250 & 20.7. 2009 & $2 \mathrm{~T} \mathrm{fl}$. & - \\
\hline $\begin{array}{l}\text { Velká kotlina, Hilitzerova skála, N facing rock wall } \\
\text { and steep slopes, leg. J. Kocián }\end{array}$ & $\begin{array}{l}50^{\circ} 03^{\prime} 15.8^{\prime \prime} \mathrm{N} \\
17^{\circ} 14^{\prime} 08.3^{\prime \prime} \mathrm{E}\end{array}$ & 1260 & 18. 7. 2015 & $7 \mathrm{~T} \mathrm{fl}$. & BRNU \\
\hline $\begin{array}{l}\text { Velká kotlina, Mildeho skalka, rock crevices, } \\
\text { not. J. Kocián }\end{array}$ & $\begin{array}{l}50^{\circ} 03^{\prime} 15,2^{\prime \prime} \mathrm{N} \\
17^{\circ} 14^{\prime} 06,6^{\prime \prime} \mathrm{E} \\
\end{array}$ & 1285 & 18. 7. 2015 & $7 \mathrm{~T} \mathrm{fl}$. & - \\
\hline $\begin{array}{l}\text { Velká kotlina, Roemerovy výchozy, rock crevices, } \\
\text { not. J. Kocián }\end{array}$ & $\begin{array}{l}50^{\circ} 03^{\prime} 14.6^{\prime \prime} \mathrm{N} \\
17^{\circ} 14^{\prime} 08.5^{\prime \prime} \mathrm{E}\end{array}$ & 1255 & 18. 7. 2015 & 9T fl. & - \\
\hline
\end{tabular}


We confirmed the occurrence of Hieracium villosum in four localities. The species can be found at five sites in Velká kotlina; L. Bureš (in litt. 2017) noticed it also on upper part of Kolenatiho skály in 1974 and on Suzova stěna during 1992-1998 but these occurrences were not confirmed recently. The species does not grow on Tabulové skály anymore (confirmed also by R. Stencl in litt. 2015). Two flowering clusters were last recorded on Volárna in 2008 by R. Štencl (Štencl 2009). L. Bureš did not find the species there in the following years although he searched the site thoroughly $-H$. villosum almost certainly does not grow on Volárna anymore (L. Bureš in litt. 2017).

It is interesting that there are two at first sight distinguishable types of Hieracium villosum in the HJM. A type growing in Velká kotlina has narrower and grassier green leaves, denticulate lower stem leaves, slightly shorter simple hairs and the whole plant is less pubescent. Meanwhile a type growing on Žárový vrch, Sokol and Praděd has broader, entire and grayish leaves, slightly longer simple hairs and whole plant is more pubescent (see Fig 7). Another noteworthy fact is that Velká kotlina is the only historically long-time known locality of this conspicuous species. Surprisingly, all other localities were discovered just recently. The origin of new localities is controversial. For example, Hruby (1914) did not report Hieracium villosum from Sokol although he performed a detailed floristical research there and reported several hawkweed species. Vicherek (1962), focusing his study on calcareous vegetation on Sokol, did not mention it either. Considering the morphological differences between the plants at the traditional locality of Velká kotlina and the plants at new localities (at least Sokol, Žárový vrch and Praděd; the plants from Volárna and Tabulové skály are documented neither by herbarium specimens nor by photos) an introduction of allochthonous plants seems to be very probable. A similar, attractive species of hawkweed, Hieracium mixtum, was recently introduced on Praděd and Žárový vrch (see above) and it is not the only case of allochthonous introduction in the HJM ( $c f$. Bureš 2013). The comparision of HJM plants with Western Carpathian ones (taxonomically solved by Severa 2001) gives another clue strengthening the introduction hypothesis: the occurrence of Hieracium villosum in the HJM is florogenetically related to the species' occurrence in the Western Carpathians and meanwhile the plants from Velká kotlina look the same as the most common Western Carpathian type of Hieracium villosum, the plants from other current localities do not resemble any type of Hieracium villosum growing in this mountain area. Further comparison with the plants from other European mountain ranges where the species occur would be crucial to resolve the origin of the plants growing on the recently discovered HJM localities.
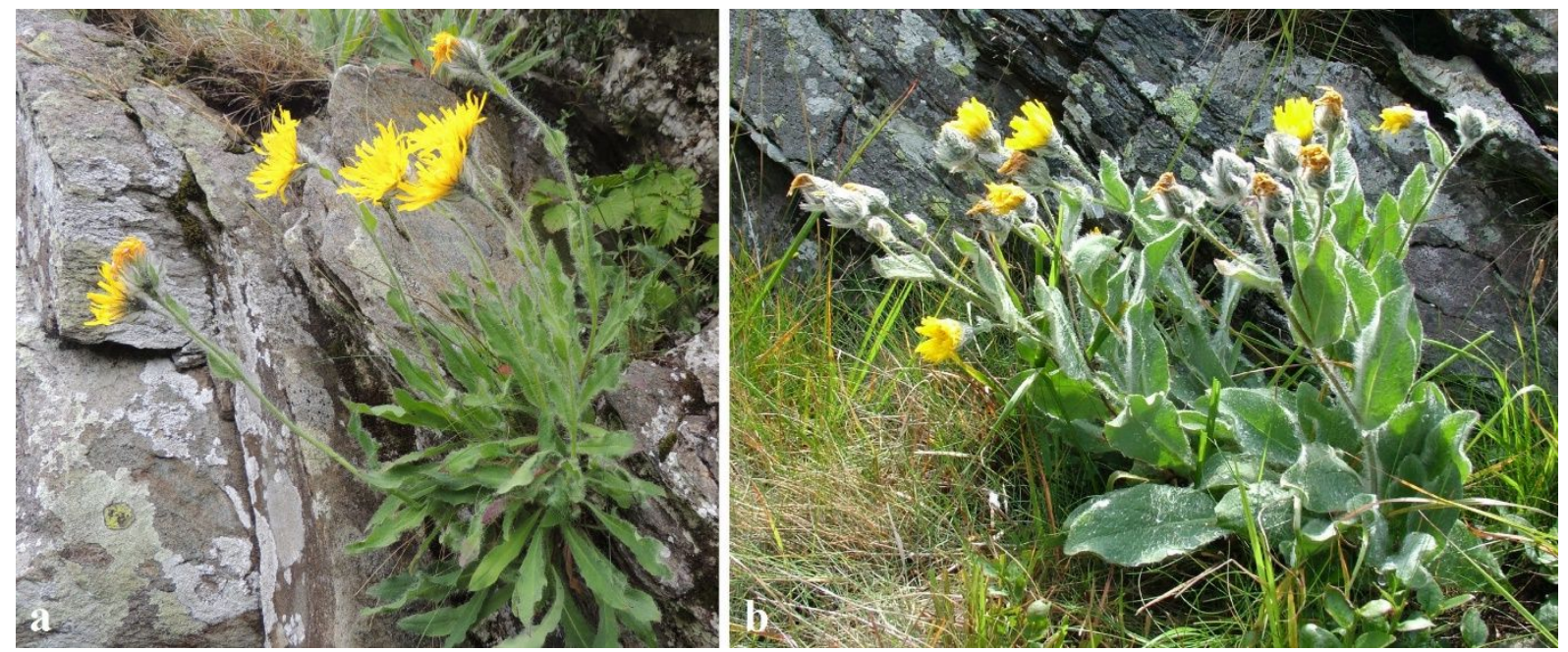

Fig 7: a - Hieracium villosum in Velká kotlina on Mildeho skalka (20. VII. 2013), b - Hieracium villosum on Sokol (10. VII. 2007). Photo a Jiří Kocián, photo b Petr Kocián. 


\section{Overall chorological data}

Figure 8 displays the number of examined herbarium specimens of each species reflecting their abundance. BRNM and BRNU were the most important herbaria for our study since they provided more than half herbarium specimens for many species. But local herbaria such as OLM and SUM were also significantly contributing since in some cases they comprised as many or even more herbarium specimens than the Czech largest herbaria PR and PRC. Some valuable specimens collected by old Silesian botanists are preserved in WRSL.

The genus Hieracium is exceedingly taxonomically difficult. Therefore, Hieracium collections are generally somewhat disordered. Thus, we surely did not find some herbarium specimens in the large herbaria, mainly in PRC. This influences the results gained by herbarium revision to some extent.

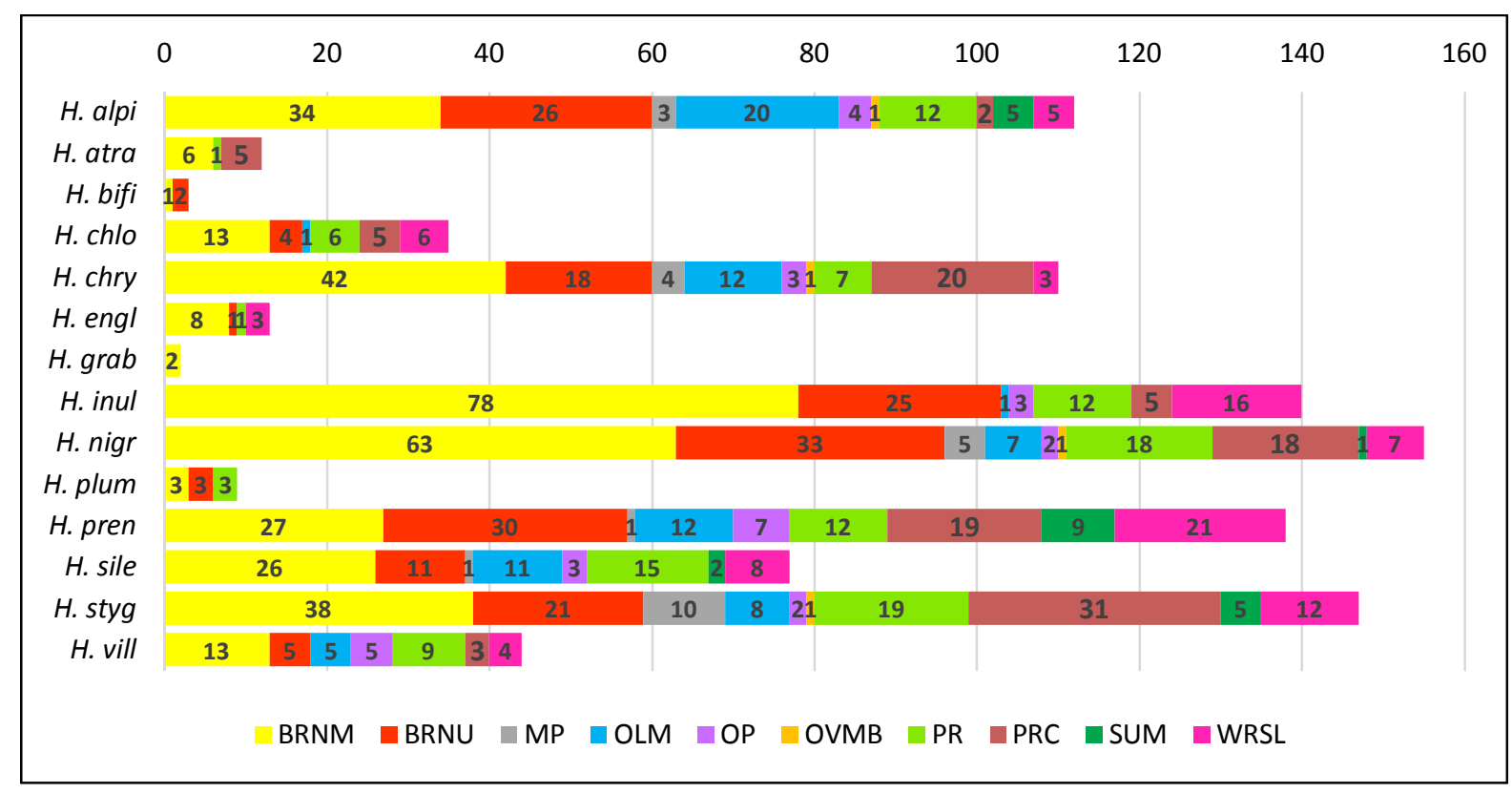

Fig 8: Number of herbarium specimens in studied herbaria.

Relatively compared numbers of herbarium specimens, herbarized plants and currently occurring plants for each species on the localities are displayed on Fig 9. There are usually several plants on one herbarium specimen, e.g. four plants per specimen on average in Hieracium alpinum (compare the first and the second column within one species). Conclusions about historical and present population sizes in each locality and the HJM in general can be made comparing the second and the third columns within one species (however, with some limitations - see Discussion).

Velká kotlina is the HJM Hieracium hotspot. All but two (Hieracium atratum agg. and $H$. plumbeum) mountain hawkweed species were historically reported from there (though the occurrence of $H$. alpinum and $H$. chrysostyloides is questionable due to their ecology - the localizations of these species to Velká kotlina refer perhaps rather to the slopes above Velká kotlina than to the glacial cirque itself). We ascertained eight species still growing in the locality - see Fig 10. 


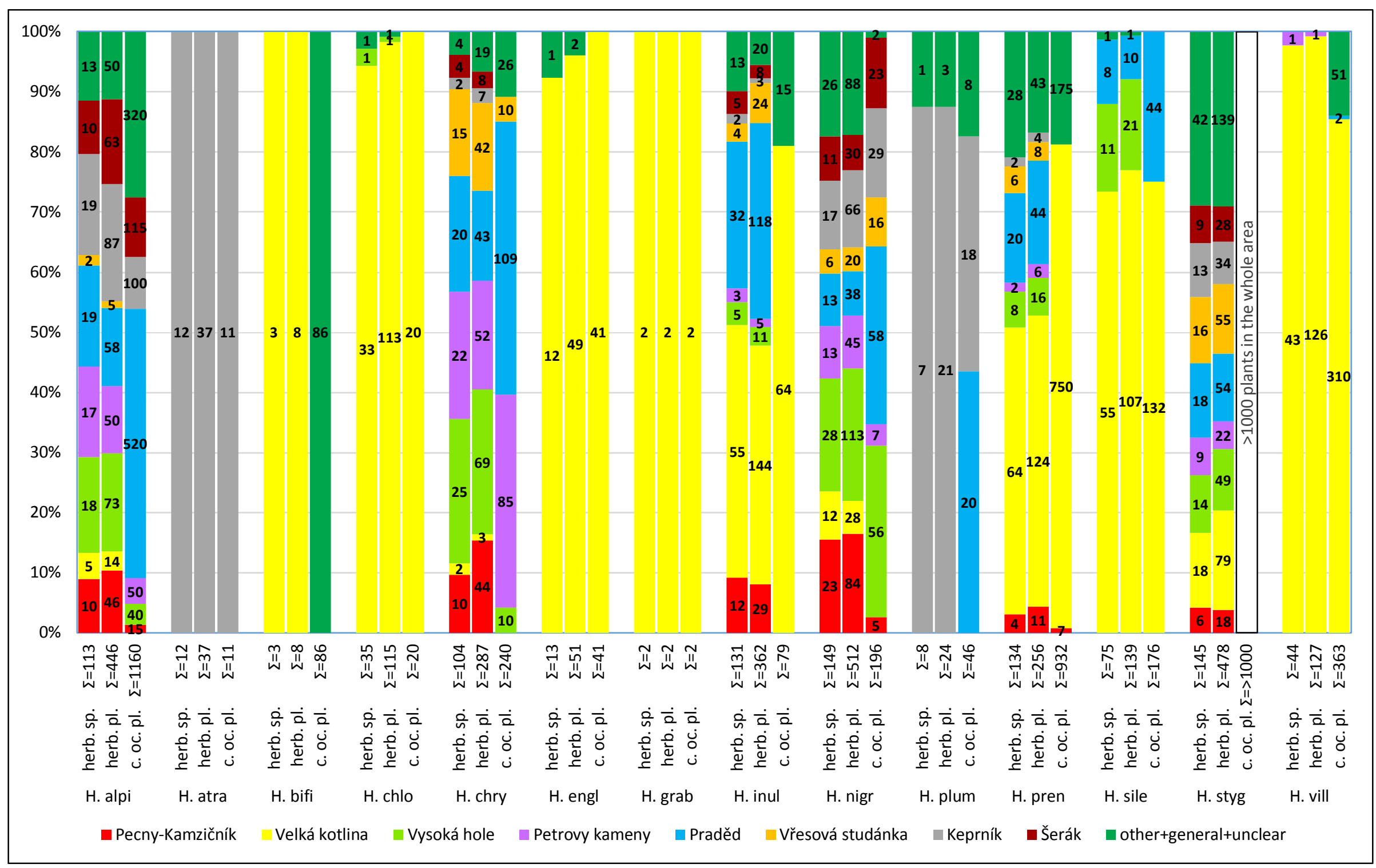

Fig 9: Relatively compared numbers of herbarium specimens (herb. sp.), herbarized plants (herb. pl.) and currently occuring plants (c. oc. pl.). 


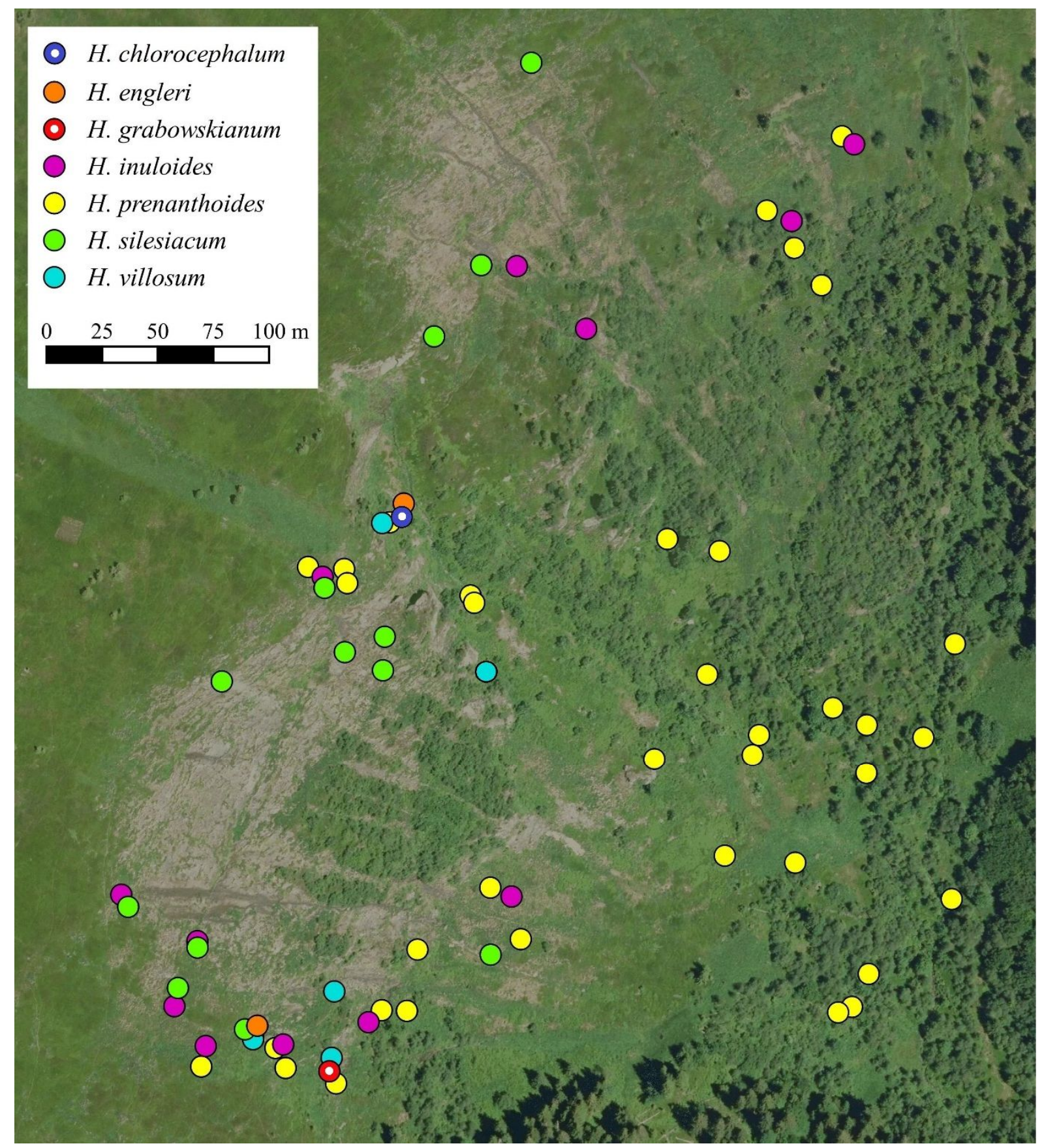

Fig 10: Contemporary distribution of mountain hawkweeds in Velká kotlina (H. stygium not displayed). Map basis - Ortophoto, 2014 C Czech Office for Surveying, Mapping and Cadastre, www.cuzk.cz.

\section{Discussion}

\section{Population sizes and changes}

Our field research was successful in confirming the contemporary occurrence of the majority of mountain hawkweeds in the HJM, providing accurate population localizations and bringing information about the current population size of the species. However, stating population size proved to be tricky since we observed relatively high interannual fluctuations in the number of flowering plants. This was caused partly due to population flowering dynamics influenced by interannual climatic fluctuations and ontogenetic developement of the plants. Another factor influencing the population size assessment was the timing of counting. Although 
we searched the localities during the flowering period of particular species, this period is narrowed down by strong herbivore grazing pressure. Grazed plants are hardly visible, so it is likely that a certain portion of plants in some localities remained uncounted. It is possible that some populations even remained undiscovered. All these factors - climatic, ontogenetic and interspecific - influenced the population size statements to some extent.

Comparing contemporary population sizes with the past ones is hard since no exact population sizes were stated in the past. Historical data consists merely of locations sometimes supplemented by generally defined population abundance. However, the number of herbarium specimens and herbarized plants collected from particular localities provides a more accurate image of population abundance (see Fig 9), although such numbers must be perceived only as relative historical abundance, moreover influenced by factors such as the species or locality attractivity. It is alarming that the number of herbarized plants from some populations of some species are higher than the number of currently occuring plants - see Fig 9 where, moreover, the disappearance of the species at some localities is demonstrated. For example, the number of currently occurring plants of Hieracium nigritum is smaller in all but one locality, ranging from between $2-80 \%$ of the number of herbarized plants. In total, the number of currently occurring plants is only $38 \%$ of the herbarized ones, and we were not able to find the species in one historical locality at all.

\section{Threatening factors influencing HJM hawkweeds negatively}

Weakening or even extinction of some populations can be ascribed to four main causes and their synergy:

(1) The most visible one is a strong grazing pressure of wild herbivore mammals. Hieracium alpinum, $H$. chrysostyloides, $H$. inuloides agg., $H$. prenanthoides agg. and $H$. silesiacum suffer by grazing the most, other species are also affected to various extents. Herbivores prefer to nibble flower heads with the upper part of the stem (see Fig 11). Meanwhile H. inuloides agg. and $H$. prenanthoides agg. are able to produce side flowering stems after the main stem is nibbled, $H$. alpinum and $H$. chrysostyloides are not so they cannot produce the seeds in the year of grazing deprivation. The herbivore most responsible for grazing is a non-native chamois which we often observed in many localities and whose negative effect on HJM plants is well known (Bureš 2013). Chamois are even more dangerous to hawkweeds because they (similarly to goats or sheep) prefer to nibble attractive flowers and avoid less attractive grasses. We observed this in many localities - hawkweeds or other attractively flowering plants were nibbled meanwhile neighbouring grasses stayed intact. But other herbivores are responsible too - we found hare excrements nearby and in the grazed clusters of H. alpinum and H. chrysostyloides on Praděd and Tabulové skály regularly. We also occasionally observed red deer and doe in Velká kotlina.

(2) Less obvious but also an important threat are the vegetation changes in the subalpine zone of the HJM, mainly the grasses density increase and undecomposed biomass accumulation. Although the processes are not completely understood yet, the main causes are historical pasturing and its cease, chemism changes by sulphur atmospheric deposition, eutrophication by nitrogen atmospheric deposition and climate change (Klimeš \& Klimešová 1991, Banaš et al. 2012). All HJM Hieracium species are rather competitively weak species. Although adult established plants seem to persist in dense and connected vegetation for long time, the seedlings are not able to establish successfully in such vegetation. There is a negative synergic effect of grazing and vegetation changes: most flowering stems are grazed and even if a few of them are saved from grazing and produce seeds successfully, there are usually no suitable patches near to the mother plants where seeds could germinate and establish new plants. Therefore, generative reproduction of many HJM hawkweed populations seems to be severely thwarted. 

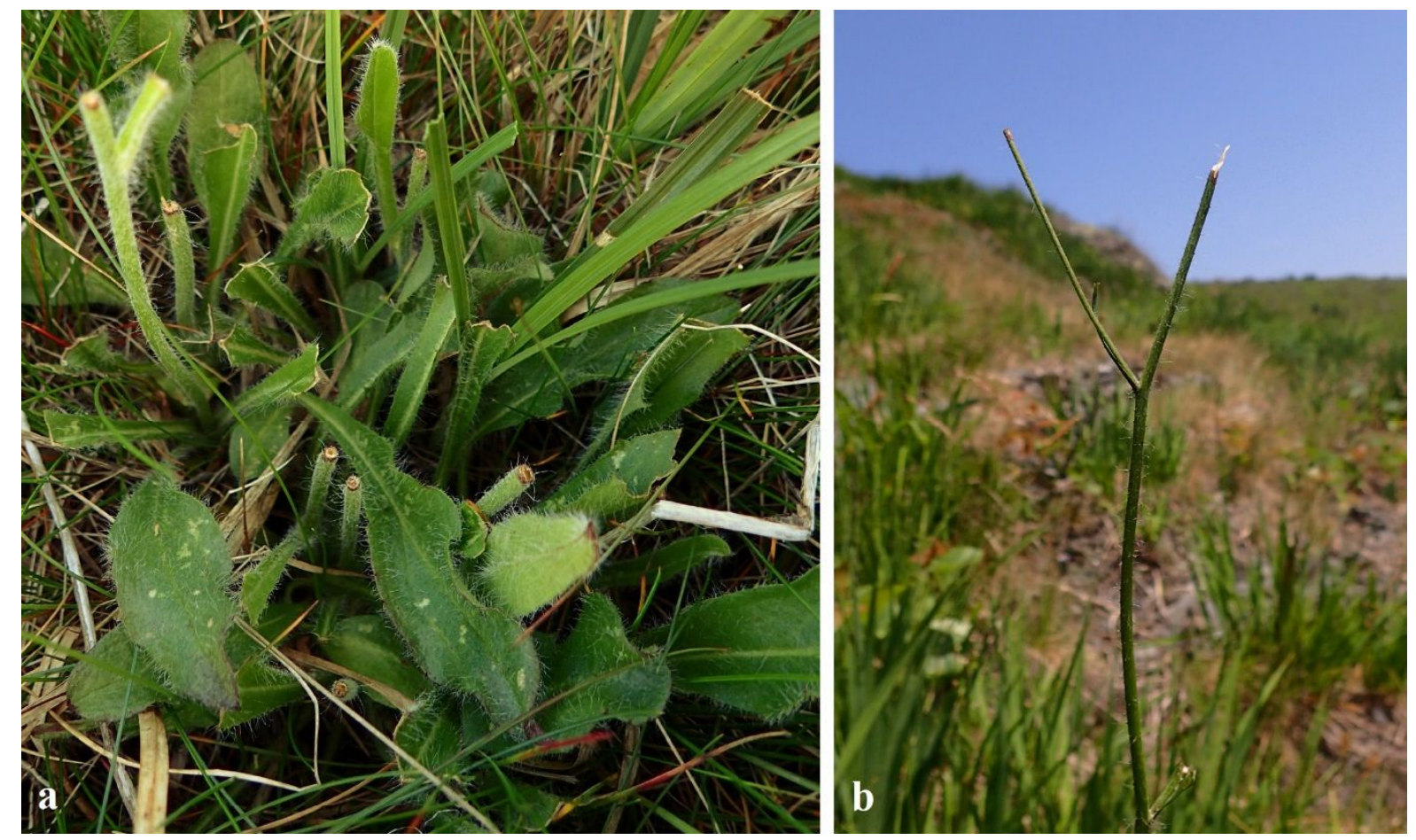

Fig 11: a - nibbled Hieracium chrysostyloides on Praděd (12. VII. 2015), b - nibbled Hieracium silesiacum in Velká kotlina (18. VII. 2015). Photos Jiř́i Kocián.

(3) The third threat is a habitat loss due to historical Pinus mugo planting. Pinus mugo is a non-native species in the HJM (Skalický 1988) which was introduced in the past in endeavour to heighten the upper limit of the forest and to prevent erosion and both snow and soil avalanches (Hošek 1963, Banaš et al. 2001). However, it influences the natural processes, subalpine ecosystems and majority of the species negatively (Bureš et al. 2009, Zeidler et al. 2012). Hawkweeds, similarly to vast majority of other subalpine plant species, are not able to grow under Pinus mugo. Since this shrubby conifer was planted mainly in the highest parts of the HJM it is a threat mainly for $H$. alpinum, $H$. chrysostyloides and H. nigritum whose populations growing close to the shrubs can be overgrown and doomed by them. This happened possibly mainly in the past since many Pinus mugo stands are dense and completely connected today. Some floristically rich localities, e.g. Hungerlehne where $H$. silesiacum was found for the first time ever (Krause 1851), were presumably destroyed just by Pinus mugo planting (Bureš et al. 2009). Nowadays the direct influence of Pinus mugo on hawkweeds is visible mainly on Šerák and Keprník. Besides, Pinus mugo plantations possess also indirect influence on subalpine ecosystems in preventing avalanches, disturbation caused by creepy snow and erosion. These natural processes are crucial for maintaining ecosystem structure and biodiversity mainly in glacial cirques (Jeník 1961).

(4) Finaly, collecting hawkweeds for herbaria certainly caused severe weakening or possibly even extinction of some populations. As mentioned above and shown on Fig 8, in some cases there are more plants in herbaria than currently growing in the localities. The collecting was not too considerate since e.g. there are four plants per one herbarium specimen on average in $H$. alpinum or $H$. engleri and three plants per one herbarium specimen on average in $H$. atratum agg., H. chlorocephalum or H. plumbeum. Fortunatelly, no HJM hawkweed species had the same destiny as Hieracium purkynei. This Krkonoše Mts endemic was exterminated just due to overcollecting (Chrtek 2004). Herbarium collecting affected HJM hawkweeds especially in the past. Nowadays, the majority of HJM mountain hawkweed localities are strictly protected in the Praděd and the Šerák-Keprník national natural reserves - collecting plants and even visiting these localities is prohibited without a special permit. 


\section{Beneficial factors influencing HJM hawkweeds positively}

On the other hand, there is one anthropogenic effect generally considered negative but it is beneficial for hawkweeds: terrain disturbation. Many populations of HJM hawkweeds grow on sites which were or are disturbed by various human activities. The vast majority of the most common HJM mountain hawkweed H. stygium populations grows on the edges of tourist paths. These are also the prefered biotope of $H$. nigritum which moreover thrives well on the historically heavily disturbed place near former Vřesová studánka chalet. Such similar places around mountain chalets are prefered also by other species: $H$. silesiacum grows near Barborka and a numerous population of $H$. prenanthoides agg. above Ovčárna and around mountain rescue service lodge. $H$. alpinum grows on the trampled surrounding of the border stone on Praděd. These examples are congruent with ecological behaviour of hawkweeds, which in general tend to grow in disturbed, less dense vegetation. This hemerophilous tendency is noticable also among many other HJM plants since anthropogenically disturbed places in HJM subalpine zone are often floristically richer than some types of natural vegetation (V. Kavalcová 2006, pers. comm.).

The above mentioned anthropogenic biotopes are only a substitute for natural biotopes where natural processes such as avalanches, creepy snow, sweeping winds or frost soil erosion maintain naturally disturbed patches prefered by hawkweeds. Conservation strategies in the HJM should focus on maintaining these processes. For example Pinus mugo stands above Velká kotlina should be removed since they impede snow accumulation in the glacial cirque and thus lessen the frequence of avalanches. This particular intention is even more important nowadays when the snowfall is decreasing due to the climate change.

\section{Conclusion}

The data provided in this article can serve as a basis for future revisions of distribution and population sizes of HJM mountain hawkweeds. The knowledge about distribution is also essential for potential further studies of the genus in the HJM. The threats to HJM hawkweeds are identified so appropriate conservational measures ought to be taken in order to protect these species which constitute an important part of biodiversity of the HJM.

Acknowledgements: We are grateful to Leo Bureš and Radek Štencl for discussing problematics of HJM Hieracium species and sharing knowledge of some Hieracium localities. We are also grateful to Petr Kocián for supporting first author during several HJM field trips and providing important literature. We thank to all the three mentioned for valuable comments to the article draft.

\section{References}

Albín R. (2005): Inventarizační průzkum NPR Šerák-Keprník 2004-2005. Ms., 69 pp. [Depon. In: AOPK ČR Správa CHKO Jeseníky, Jeseník].

- (2006): Inventarizace vyšších rostlin a rostlinných společenstev v navrhované přírodní rezervaci Břidličná. Ms., 70 pp. [Depon. In: AOPK ČR Správa CHKO Jeseníky, Jeseník].

Banaš M., Treml V., Lekeš V. \& Kuras T. (2001): Několik poznámek ke stanovení alpinské hranice lesa ve Východních Sudetech. pp. 109-128. In: Létal A., Szczyrba Z. \& Vysoudil M. [eds]: Sborník příspěvků výroční konference České geografické společnosti - "Česká geografie v období rozvoje informačních technologií", 25.-27.9.2001. Univerzita Palackého v Olomouci, Olomouc.

Banaš M., Zeidler M. \& Zahradník D. (2012): Ovlivňují globální změny prostředí alpinskou tundru Krkonoš, Králického Sněžníku a Hrubého Jeseníku? - Ochrana přírody 3/2012: 14-17.

Bräutigam S. (1992): Hieracium L. pp. 325-333 et 550-560. In: Meusel H. \& Jäger E.J. [eds]: Vergleichende Chorologie der zentraleuropäischen Flora 3. Gustaf Fischer Verlag, Jena, Stuttgart, New York.

Bureš L. (2013): Chráněné a ohrožené rostliny chráněné krajinné oblasti Jeseníky. Rubico, Olomouc, 314 pp. 
Bureš L., Kočvara R., Kuras T. \& Hradecký J. (2009): Problematika kleče v Hrubém Jeseníku. pp. 9-63. In: Vítek O. [ed.]: Analýza antropických vlivů v nejcennějších částech CHKO Jeseníky. AOPK ČR, Praha.

Fiek E. (1881): Flora von Schlesien preussischen und österreichischen Anteils, enthaltend die wildwachsenden, verwilderten und angebauten Phanerogamen und Gefäss-Cryptogamen. J.U. Kern's Verlag, Breslau, 571 pp.

Formánek E. (1886): Beitrag zur Flora der Karpathen und des Hochgesenkes. - Oesterr. Bot. Z. 36/7: 232-237.

Fries E. (1862): Epicrisis generis Hieraciorum. Upsala Universitets Årsskrift, Upsala, 158 pp.

Grabowski H. (1843): Flora von Ober-Schlesien und dem Gesenke, mit erücksichtigung der geognostischen, Boden- und Höhen- Verhältnisse. Gosohorsky, Breslau, 451 pp.

Hošek E. (1963): Zalesňování horských holí v okolí Pradědu. - Čas. Slez. Muz. Opava (C) 2(12): 43-50.

Hruby J. (1914): Die Ostsudeten. Eine Floristische Skizze. Verlag der Landesdurchforschungs-Kommission Druck von W. Burkart, Brünn, 136 pp.

Chrtek J. (1995): Notes on Hieracium alpinum and Hieracium nigrescens (section Alpina Fries) in the Eastern Sudeten (Mt. Králický Sněžník, the Hrubý Jeseník Mts) - Preslia 67: 97-106.

- (1996): Chromosome numbers in selected Hieracium species (Compositae) in the Sudeten Mts and West and Ukrainian East Carpathians. - Fragm. Florist. Geobot. 41: 783-790.

- (2004): Hieracium L. - jestráb́bník. pp. 540-701. In: Slavík B. \& Štěpánková J. [eds]: Květena České republiky. Vol. 7. Academia, Praha.

Chrtek J., Szeląg Z., Mráz P. \& Severa M. (2002): Hieracium silesiacum Krause [Hieracium sparsum subsp. silesiacum (Krause) Zahn] v Západních Karpatech. - Bull. Slov. Bot. Spoloč. 24: 81-90.

Jeník J. (1961): Alpinská vegetace Krkonoš, Králického Sněžníku a Hrubého Jeseníku: teorie anemoorografických systémů. Nakladatelství ČSAV, Praha, 409 pp.

Jeník J., Bureš L. \& Burešová Z. (1983a): Revised flora of Velká kotlina Cirque, the Sudeten Mountains, I. Preslia 55: 25-61.

- (1983b): Revised flora of Velká kotlina Cirque, the Sudeten Mountains, II. - Preslia 55: 123-141.

Kaplan Z., Danihelka J., Lepší M., Lepší P., Ekrt L., Chrtek J., Kocián J., Prančl J., Kobrlová L., Hroneš M. \& Šulc V. (2016): Distributions of vascular plants in the Czech Republic. Part 3. - Preslia 88: 459-544.

Klimeš L. \& Klimešová J. (1991): Alpine tundra in the Hrubý Jeseník Mts, the Sudeten, and its tentative developement in the 20th century. - Preslia 63: 245-268.

Kocián J. \& Chrtek J. (2011): Hieracium mixtum Froel s. 1. In: Hadinec J. \& Lustyk P. [eds]: Additamenta ad floram Reipublicae Bohemicae. IX. - Zprávy Čes. Bot. Spol. 46: 116-118.

Kocián J. (2012): Rozšíření a cytogeografie jestřábníku věsenkovitého (Hieracium prenanthoides Vill.) v Sudetech a Západních Karpatech. Ms. Bachelor theses, 69 pp. [Depon. In: Univerzita Palackého v Olomouci, Př́rodovědecká fakulta, Katedra botaniky, Olomouc].

- (2013): Reprodukční systémy polyploidního komplexu Hieracium prenanthoides. Ms. Master theses, 65 pp. [Depon. In: Univerzita Palackého v Olomouci, Př́rodovědecká fakulta, Katedra botaniky, Olomouc].

Kočí M. (2005): Inventarizační průzkum NPR Praděd - flóra a vegetace. Ms., 38 pp. [Depon. In: AOPK ČR Správa CHKO Jeseníky, Jeseník].

- (2009): Aktualizace mapovacího okrsku cz0782, Aktualizace vrstvy mapování biotopů ČR. AOPK ČR, Praha.

Krause E. (1851): Ueber zwei neue Pflanzenformen aus der schlesischen Flora. - Jahresber. Schles. Ges. Vaterl. Kultur 28: 101-102.

Mateo G. (2007): Los géneros Hieracium y Pilosella en el ámbito de Flora Iberica [online]. [cit. 1. 7. 2017]. Available from: http://www.floraiberica.es/floraiberica/texto/borradores/vol_XVI/Hieracium.pdf

Mráz P. (2005): Hieracium silesiacum (Asteraceae) in Poland. - Polish Bot. J. 50: 65-68.

Novotná S, Danihelka J., Rotreklová O. \& Chrtek J. (2014): Jestřábník okoličnatý (Hieracium umbellatum) v České republice. - Acta Rer. Natur. 15: 73-95.

Oborny A. (1885): Flora von Mähren und österr. Schlesien. Commissionsverlag der k. k. Hof-Buchhandlung Carl Winiker, Brunn, 760 pp.

- (1906): Die Hieracium aus Mähren und österr. Schlesien. H. Untergattung Euhieracium Torr. et Gray. - Verh. Naturforsch. Ver. Brünn 44: 1-79.

Pulkina S.V. \& Tupitsyna N.N. (2000): Poliploidnye kompleksy v rode Hieracium (Asteraceae). Turczaninowia 3: 79-81.

Ronikier M. \& Szeląg Z. (2008): Differentiation among disjunct populations of agamospermous species of Hieracium section Cernua (Asteraceae) in Central European subalpine habitats. - Bot. J. Linn. Soc. 158: 93105.

Sennikov A.N. (2005): A taxonomic and nomenclatural note on Hieracium caesium (Asteraceae). - Nord. J. Bot. 23: 305-314.

Severa M. (2001): Hieracium villosum Jacq. a př́buzné druhy Západních Karpat a Sudet. Ms. Master theses, 77 pp. [Depon. In: Univerzita Karlova, Př́rodovědecká fakulta, Katedra botaniky, Praha]. 
Skalický V. (1988): Pinus mugo Turra. - borovice kleč, kosodřevina. pp. 294-296. In: Hejný S. \& Slavík B. [eds]: Květena České socialistické republiky. Vol. 1. Academia, Praha.

Skřiván ek V. (1956): Příspěvek k rozšíření rodu Hieracium v Hrubém Jeseníku. - Přírod. Sborn. Ostrav. Kraje 17: 397-405.

Stace C.A., Gornall R.J. \& Shi Y. (1995): Chromosome numbers in Hieracium L. Section Alpina (Fries) F. N. Williams. - Watsonia 20: 367-377.

Szeląg Z. (2004): Taxonomic and nomenclatural notes on Hieracium silesiacum (Asteraceae). - Polish Bot. J. 49: $15-20$.

- (2003): A synopsis of Hieracium sect. Cernua (Asteraceae). - Polish Bot. J. 48: 89-97.

Šten cl R. (2009): Monitoring významných druhů rostlin CHKO Jeseníky. Hieracium villosum. Ms., 3 pp. [Depon. In: AOPK ČR Správa CHKO Jeseníky, Jeseník].

Thiers B. (2017): Index Herbariorum: A global directory of public herbaria and associated staff. New York Botanical Garden's Virtual Herbarium [online]. [cit. 1. 7. 2017]. Available from: http://sciweb.nybg.org/science2/IndexHerbariorum.asp

Tyler T. \& Jönsson J. (2009): Ploidy level analysis of apomictic Hieracium (Asteraceae) reveal unexpected patterns and variation. - Nordic J. Bot. 27: 490-502.

Uechtritz R. (1871): Ein neues Hieracium der schlesischen Hochgebirge. - Oesterr. Bot. Z. 21: 293-295.

Vich erek J. (1962): Zapomenutá lokalita Aster alpinus L. v Hrubém Jeseníku. - Přírod. Čas. Slez. 23: 368-369.

Wimmer F. \& Grabowski H. (1829): Flora Silesiae. Pars secunda, Vol. II, Cl. XVI-XXII. Korn, Vratislavia, $400 \mathrm{pp}$.

- (1840): Flora von Schlesien preussischen und österreichischen Antheils. F. Hirt, Breslau, 48, 464, 82 pp.

Zahn K.H. (1921-1923): Hieracium. pp. 1-1146. In: Engler A. [ed.]: Das Pflanzenreich. Wilhelm Engelmann, Leipzig.

- (1922-1938): Hieracium. pp. 1-708. In: Graebner P. [ed.]: Synopsis der mitteleuropäischen Flora XII/1-3. Gebrüder Borntraeger, Leipzig.

Zavadil V. (2007): Taxonomická a ekologická studie okruhu Hieracium bifidum Kit. ex Hornem. na území ČR. Ms. Master theses, 85 pp. [Depon. In: Univerzita Karlova, Př́rodovědecká fakulta, Katedra botaniky, Praha].

Zeidler M., Duchoslav M., Banaš M. \& Lešk ová M. (2012): Impacts of introduced dwarf pine (Pinus mugo) on the diversity and composition of alpine vegetation. - Community Ecol. 13(2): 213-220.

Authors' addresses: Jiří Kocián, Nature Conservation Agency of the Czech Republic, Kaplanova 1,

CZ-148 00 Prague, Czech Republic.

E-mail: jikocian@seznam.cz

Jindřich Chrtek, Institute of Botany, The Czech Academy of Sciences, Zámek 1, CZ-252 43 Průhonice, Czech Republic.

E-mail: chrtek@ibot.cas.cz 